\title{
1.
}

\section{TAFI-II, A COMPUTER CODE FOR MANAGEMENT OF RADIOACTIVE WASTE

\author{
C.R. Tharin
}

SRL

RECORD COPY

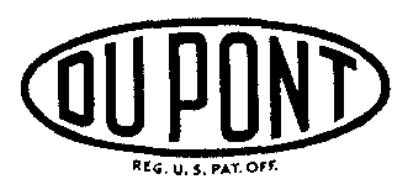

Savannah River Laboratory

Aiken, South Carolina 


\section{LEG A L NOTICE}

This report was prepared as an account of Government sponsored work. Neither the United States, nor the Commission, nor any person acting on behalf of the Commission:

A. Makes any warranty or representation, expressed or implied, with respect to the accuracy, completeness, or usefulness of the information contained in this report, or that the use of any Information, apparatus, method, or process disclosed in this report may not infringe privately owned rights; or

B. Assumes any liabilities with respect to the use of, or for damages resulting from the use of any information, apparatus, method, or process disclosed in this report.

As used in the above, "person acting on behalf of the Commission" includes any employee or contractor of the Commission, or employee of such contractor, to the extent that such employee or contractor of the Commission, or employee of such contractor prepares, disseminates, or provides access to, any information pursuant to his employment or contract with the Commission, or his employment with such contractor.

Printed in USA. Price $\$ 2.00$

Avallable from the Clearinghouse for Federal Sclentific and Technical Information, National Bureau of Standards,

U. S. Department of Commerce, Springfield, Virginia 
TAFI - II, A COMPUTER CODE FOR MANAGEMENT OF RADIOACTIVE WASTE

by

Catherine R. Tharin

Approved by

J. W. Wade, Research Manager Applied Mathematics Division

August 1965

E. I. DU PONT DE NEMOURS \& COMPANY SAVANNAH RIVER LABORATORY

AIKEN, SOUTH CAROLINA

CONTRACT AT(07.2).1 WITH THE

UNITED STATES ATOMIC ENERGY COMMISSION 


\begin{abstract}
A computer program, TAFI-II, was written in FORTRAN II to assist in the regulation and inventory control of radioactive fission products that are stored in waste tanks at the Savannah River Plant. The inventories and heat generation rates are computed for thirteen isotopes in each of twenty-four waste tanks. The program prepares a report that summarizes the data and provides an up-to-date status of the conditions in the waste tanks.
\end{abstract}




\section{CONTENTS}

$\begin{array}{lc}\text { Introduction } & \text { Page } \\ \text { Description of the Waste Tank Farm } & 4 \\ \text { Equations Used in Computer Program } & 4 \\ \text { Isotopic Concentration at Reactor Discharge } & 4 \\ \text { Effect of Radioactive Decay } & 5 \\ \text { Heat Generation } & 6 \\ \text { Distribution of Isotopes between Supernate and Sludge } & 6 \\ \text { Intertank Transfers } & 7 \\ \text { Description of the Computer Program } & 7 \\ \text { Main Program } & -9 \\ \text { Subroutine PART I } & 11 \\ \text { Subroutine PART 2 } & 11 \\ \text { Subroutine PART 3 } & 11 \\ \text { Subroutine PART } 4 & 12 \\ \text { Acknowledgment } & 12 \\ \text { References } & 14 \\ \text { Appendix A - FORTRAN Listing } & 14 \\ \text { Appendix B - Input Data Formats and Sample Problem } & 15 \\ & 30 \\ & \end{array}$

\section{Figure}

1 Over-All Flow 10

2 Subroutine PART 3 Flow 13 


\section{TAFI-II, A COMPUTER CODE FOR MANAGEMENT OF RADIOACTIVE WASTE}

\section{INTRODUCTION}

The chemical separations processes at the Savannah River Plant generate large volumes of aqueous waste that, because of their high fission product content and resultant gamma heat, are stored in cooled underground steel tanks until the short-lived isotopes have decayed to low levels. During this storage time the wastes separate into two layers: the sludge layer at the bottom containing about $85 \%$ of the total activity, and the liquid fraction or supernate containing the remainder of the isotopes. After the waste has decayed and separated for some time, the supernate is removed and concentrated by evaporation. The residue from the evaporation is then stored in uncooled tanks (1) to decay and separate further. To schedule and regulate movement of the waste, it is necessary to know the inventory of fission products and the heat generation rates in each tank. To assist in this, a computer code, TAFI-II, was written to facilitate these calculations and prepare reports at regular intervals.

\section{DESCRIPTION OF THE WASTE TANK FARM}

The waste tank farm consists of twelve tanks and one evaporator in each of the two chemical separations areas, $F$ and $H$. The tanks are numbered in the order in which they were built. Tanks numbered 1-8 and 17-20 are in F Area, and 9-16 and 21-24 are in H Area. The tanks in each area are connected to the chemical separations bulldings and to each other by shielded pipes through which the separations process waste is added, transferred from tank to tank, or transferred from one tank to another through the evaporator. At the present time there is no physical connection between the areas. Tanks 1-16 are cooled and receive fresh waste from the separations processes; tanks 17-24 are uncooled $(1)$ and receive the evaporator bottoms.

\section{EQUATIONS USED IN COMPUTER PROGRAM}

The equations used to compute the concentrations of the 13 isotopes are described below. The 13 isotopes are: ${ }^{89} \mathrm{Sr},{ }^{80} \mathrm{Sr},{ }^{90} \mathrm{Y},{ }^{91} \mathrm{Y},{ }^{95} \mathrm{Zr}$, ${ }^{95} \mathrm{Nb},{ }^{108} \mathrm{Ru},{ }^{108} \mathrm{Rh},{ }^{137} \mathrm{Cs},{ }^{137} \mathrm{Ba},{ }^{144} \mathrm{Ce},{ }^{144} \mathrm{Pr}$, and ${ }^{147} \mathrm{Pm}$. These particular 1sotopes are of interest in management of the waste because they (a) represent a long-term health hazard, (b) account for about 95\% of the heat generation which is within the accuracy of measurements 
that can be made in waste tanks, or (c) may be of interest for future recovery. In the equations below the index $J$ is used to define the isotope as it appears in this list; e.g., $\mathrm{J}=4^{91} \mathrm{Y}$.

In addition to the above 13 isotopes, the waste tanks contain small quantities of alpha emitters: ${ }^{238} \mathrm{U},{ }^{235} \mathrm{U},{ }^{239} \mathrm{Pu}$, and ${ }^{238} \mathrm{Pu}$. Because of their long half-lives, they are treated as if they were stable, and in the intertank transfers it is assumed that they follow the sludge.

\section{Isotopic Concentration at Reactor Discharge}

Equations 1-5 are used to compute the isotopic concentrations of an addition to the tank farm system at the end of the reactor irradiation. The concentrations
and ${ }^{147} \mathrm{Pm}$ are given by

$$
A_{J}^{0}=K P Y_{J}\left(1-e^{-a_{J}^{T}}\right) \quad J=1,2,4,5,7,9,11,13
$$

The concentrations of ${ }^{90} \mathrm{Y},{ }^{95} \mathrm{Nb},{ }^{108} \mathrm{Rh}$, and ${ }^{144} \mathrm{Pr}$, which are daughters of ${ }^{90} \mathrm{Sr},{ }^{95} \mathrm{Zr},{ }^{106} \mathrm{Ru}$, and ${ }^{144} \mathrm{Ce}$, respectively, are given by

$$
A_{J}^{\circ}=\operatorname{KP} Y_{J}\left\{\left[\left(\frac{a_{J}}{a_{J}-a_{J-1}}\right)\left(1-e^{-a_{J-1} T}\right)\right]-\left[\left(\frac{a_{J}-1}{a_{J}-a_{J-1}}\right)\left(1-e^{-a_{J} T}\right)\right]\right\}
$$

The ${ }^{137} \mathrm{Ba}(\mathrm{J}=10)$ concentration is assumed to be $92 \%$ of the ${ }^{137} \mathrm{Cs}$ concentration since $8 \%$ of the ${ }^{137} \mathrm{Cs}$ decays directly to the stable ${ }^{137} \mathrm{Ba}$ isomer. Thus

$$
A_{J}^{0}=0.92 A_{J-1}^{\circ} \quad J=10
$$

where

$$
\begin{aligned}
& \mathrm{A}_{J}^{\circ}=\text { initial concentration for isotope } \mathrm{J} \text {, curies/addition } \\
& \mathrm{K}=\left(\frac{\left(3.16 \times 10^{16} \text { fissions } / \mathrm{sec} / \mathrm{MW}\right)}{\left(3.7 \times 10^{10} \text { disintegrations/sec/curie }\right)}\right)=0.85 \times 10^{8} \text { curies } / \mathrm{MW} \\
& \mathrm{Y}_{\mathrm{J}}=\text { fractional yield, atoms/fission } \\
& \mathrm{a}_{\mathrm{J}}=0.693 / \text { half-life, days }{ }^{-1} \\
& \mathrm{~T}=\text { irradiation, days }
\end{aligned}
$$


For processing of highly enriched fuel the value of $P$ in Equations $I$ and 2 is expressed in terms of the ${ }^{235} \mathrm{U}$ burnup per tube as follows:

$$
\mathrm{P}=\left[\frac{235 \mathrm{U} \text { burnup, grams/tube }}{1.245 \text { grams }{ }^{235} \mathrm{U} / \mathrm{MWD}}\right]\left[\frac{\text { No. tubes/addition }}{\mathrm{T}, \text { days }}\right] \text {, MW/addition }
$$

whereas for processing of natural uranium fuel, $P$ is expressed by

$$
P=(\text { Megawatts/Ton of } U) \text { (Tons of U/addition) }
$$

\section{Effect of Radioactive Decay}

These equations are used to compute the effect of radioactive decay of the isotopes while they are in the reactor, from time-ofdischarge until they are added to the waste tanks, and after they are in the waste system until the concentration reaches $10^{-5}$ curie at which time the concentration is set to zero.

Mother

$$
B_{J}=A_{J}^{0} e^{-a_{J} T} \quad J=1,2,4,5,7,9,11,13
$$

Daughter

$$
\begin{gathered}
B_{J}=\left[A_{J-I}^{0}\left(\frac{a_{J}}{a_{J}-a_{J-1}}\right)\left(e^{-a_{J}-1} T-e^{-a_{J} T}\right)\right]+A_{J}^{0} e^{-a_{J} T} \quad J=3,6,8,12 \\
B_{J}=0.92 A_{J-1}^{0} \quad J=10
\end{gathered}
$$

where

$$
\begin{aligned}
& B_{J}=\text { concentration of isotope } \mathrm{J} \text {, curies } \\
& T=\text { decay time, days } \\
& a_{J}=0.693 / \text { half-life, days }
\end{aligned}
$$

\section{Heat Generation}

The decay heat, $Q_{J}$, is computed from the concentration of each isotope, $\mathrm{B}_{J}$, and a parameter $\mathrm{H}_{J}$, the energy release per disintegration.

$$
Q_{J}=B_{J} H_{J} \quad J=1,13
$$




\section{Distribution of Isotopes between Supernate and Sludge}

In the process of cooling for 2 to 3 years the waste separates into two layers, the supernate and sludge. The heavier sludge layer contains about $85 \%$ of the total activity in a tank. Each of the 13 isotopes has a partition factor, $\mathrm{PF}_{J}$, which is defined as the fraction of the isotope in the supernate of a tank. These partition factors range from 0.02 for ${ }^{89} \mathrm{Sr}$ to 0.95 for ${ }^{137} \mathrm{Cs}$.

\section{Intertank Transfers}

Four types of intertank transfers can be made in the operation of the tank farm. The types are defined by the material transferrec, supernate or sludge, and whether or not the material being moved has its partition factors changed while in transit. The curies to be transferred in a supernate transfer are computed by

$$
\mathrm{CT}_{\mathrm{J}}=\mathrm{TB}_{\mathrm{J}} \mathrm{PF}_{\mathrm{J}} \mathrm{PC} \quad \mathrm{J}=1,13
$$

and in a sludge transfer by

$$
\mathrm{CT}_{J}=\mathrm{TB}_{\mathrm{J}} \mathrm{PC}\left(1.0-\mathrm{PF}_{\mathrm{J}}\right) \quad \mathrm{J}=1,13
$$

where

$$
\begin{aligned}
\mathrm{CT}_{J}= & \text { curies transferred, isotope } \mathrm{J} \\
\mathrm{TB}_{J}= & \text { total curies of isotope } \mathrm{J} \text { in tank from which material } \\
& \text { is removed }
\end{aligned}
$$

Thus, total curies in the tanks after a transfer are

$$
\mathrm{NTB}_{\mathrm{J}}=\mathrm{TB}_{\mathrm{J}}-\mathrm{CT}_{\mathrm{J}} \quad \mathrm{J}=1,13
$$

for the sending tank, and

$$
\mathrm{NTB}_{\mathrm{J}}=\mathrm{TB}_{\mathrm{J}}+\mathrm{CT}_{\mathrm{J}} \quad \mathrm{J}=1,13
$$

for the receiving tank for all types of transfers. 


\section{Supernate Transfers}

In supernate transfers the new partition factors $\left(\mathrm{NPF}_{\mathrm{J}}\right)$ for the tank from which material is removed are calculated by

$$
N P F_{J}=\frac{\left(\mathrm{PF}_{\mathrm{J}} \mathrm{TB}_{\mathrm{J}}\right)-\mathrm{CT}_{\mathrm{J}}}{\left(\mathrm{TB}_{\mathrm{J}}-\mathrm{CT} \mathrm{T}_{\mathrm{J}}\right)} \quad \mathrm{J}=1,13
$$

and the new partition factors for the recelving tank are calculated by

$$
N P F_{J}=\frac{\left(\mathrm{PF}_{\mathrm{J}} \mathrm{TB}_{\mathrm{J}}\right)+\mathrm{CT}_{\mathrm{J}}}{\left(\mathrm{TB}_{\mathrm{J}}+\mathrm{CT}_{\mathrm{J}}\right)} \quad \mathrm{J}=1,13
$$

However, if some of the material is precipitated by passing it through an evaporator, the new partition factors for the receiving tank are calculated by

$$
\mathrm{NPF}_{\mathrm{J}}=\frac{\left(\mathrm{PF}_{\mathrm{J}} \mathrm{TB}_{\mathrm{J}}\right)+\left(\mathrm{CT}_{\mathrm{J}} \mathrm{PFA}_{\mathrm{J}}\right)}{\left(\mathrm{TB}_{\mathrm{J}}+\mathrm{CT}_{\mathrm{J}}\right)} \quad \mathrm{J}=1,13
$$

where

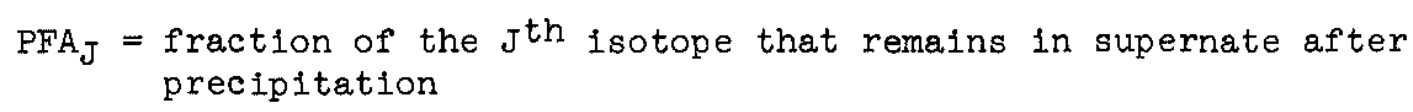

\section{Sludge Transfers}

In sludge transfers the new partition factors for the sending tank are recomputed by

$$
\mathrm{NPF}_{\mathrm{J}}=\frac{\left(\mathrm{PF}_{\mathrm{J}} \mathrm{TB}_{\mathrm{J}}\right)}{\left(\mathrm{TB}_{\mathrm{J}}-\mathrm{C} \mathrm{T}_{\mathrm{J}}\right)} \quad \mathrm{J}=1,13
$$

The new partition factors for the receiving tank are computed from

$$
\mathrm{NPF}_{\mathrm{J}}=\frac{\left(\mathrm{PF}_{\mathrm{J}} \mathrm{TB}_{\mathrm{J}}\right)}{\left(\mathrm{TB}_{\mathrm{J}}+\mathrm{CT}_{\mathrm{J}}\right)} \quad \mathrm{J}=1,13
$$

and, as in the case of a supernate transfer in which some of the material is precipitated, the new partition factors for the receiving tank are given by

$$
\mathrm{NPF}_{J}=\frac{\left(\mathrm{PF}_{J} \mathrm{~TB}_{\mathrm{J}}\right)}{\mathrm{TB}_{J}+\left(\mathrm{CT}_{J} \mathrm{PFA}_{J}\right)} \quad \mathrm{J}=1,13
$$




\section{Transfer of Alpha Emitters}

The alpha emitters are assumed to be contained completely in the sludge. The concentrations of the $\mathrm{N}$ isotopes are given by the following expressions in which $\mathrm{N}=1,4$ and corresponds to ${ }^{238} \mathrm{U},{ }^{235} \mathrm{U},{ }^{239} \mathrm{Pu}$, and the combined total of the ${ }^{238} \mathrm{Pu}$ and ${ }^{239} \mathrm{Pu}$.

$$
\begin{array}{cc}
\mathrm{UP}_{\mathrm{N}}=\mathrm{STUP}_{\mathrm{N}} \mathrm{PC} & \mathrm{N}=1,4 \\
\mathrm{NTUP}_{\mathrm{N}}=\mathrm{STUP}_{\mathrm{N}}-\mathrm{UP}_{\mathrm{N}} & \mathrm{N}=1,4 \\
\mathrm{RNTUP}_{\mathrm{N}}=\mathrm{RTUP}_{\mathrm{N}}+\mathrm{UP}_{\mathrm{N}} & \mathrm{N}=1,4
\end{array}
$$

where

$$
\begin{aligned}
& \mathrm{UP}_{\mathrm{N}}=\text { fraction of alpha emitter } \mathrm{N} \text { that is transferred } \\
& \mathrm{STUP}_{\mathrm{N}}=\text { total of alpha emitter } \mathrm{N} \text { in the sending tank } \\
& \mathrm{NTUP}_{\mathrm{N}}=\text { new total in sending tank } \\
& \mathrm{RNTUP}_{\mathrm{N}}=\text { new total in receiving tank }
\end{aligned}
$$

\section{DESCRIPTION OF THE COMPUTER PROGRAM}

TAFI-II was written in FORTRAN II for an IBM 704 with 10 tapes and a core memory of 32,000 words. The over-all flow is shown in Figure 1 and the FORTRAN listing is given in Appendix. A. The code consists of the main program and four subroutines. COMMON is used to transfer data between the different parts of the code.

To allow for future expansion of the tank farm, as many as 34 tanks can be used with no changes to the code. Future tanks 25-28 have been assigned to $H$ Area and 29-32 to F Area. The possibllity of storing waste in deep-mined caverns (2) has been considered by assigning tank number 33 to F Area and tank number 34 to $\mathrm{H}$ Area as deep-mined caverns. A transfer of waste into any one of these tanks is all that is necessary to put that tank into the TAFI-II system.

The summary of contents and conditions in each tank, permanent library data, is kept as a consecutively numbered series of binary records on a library tape. The library tape is updated at the end of each job by Subroutine PART 4. Each record, called file on the control card, includes the file (record) number, the year, month, day for the job, the final gamma and alpha emitter concentrations, and the final 


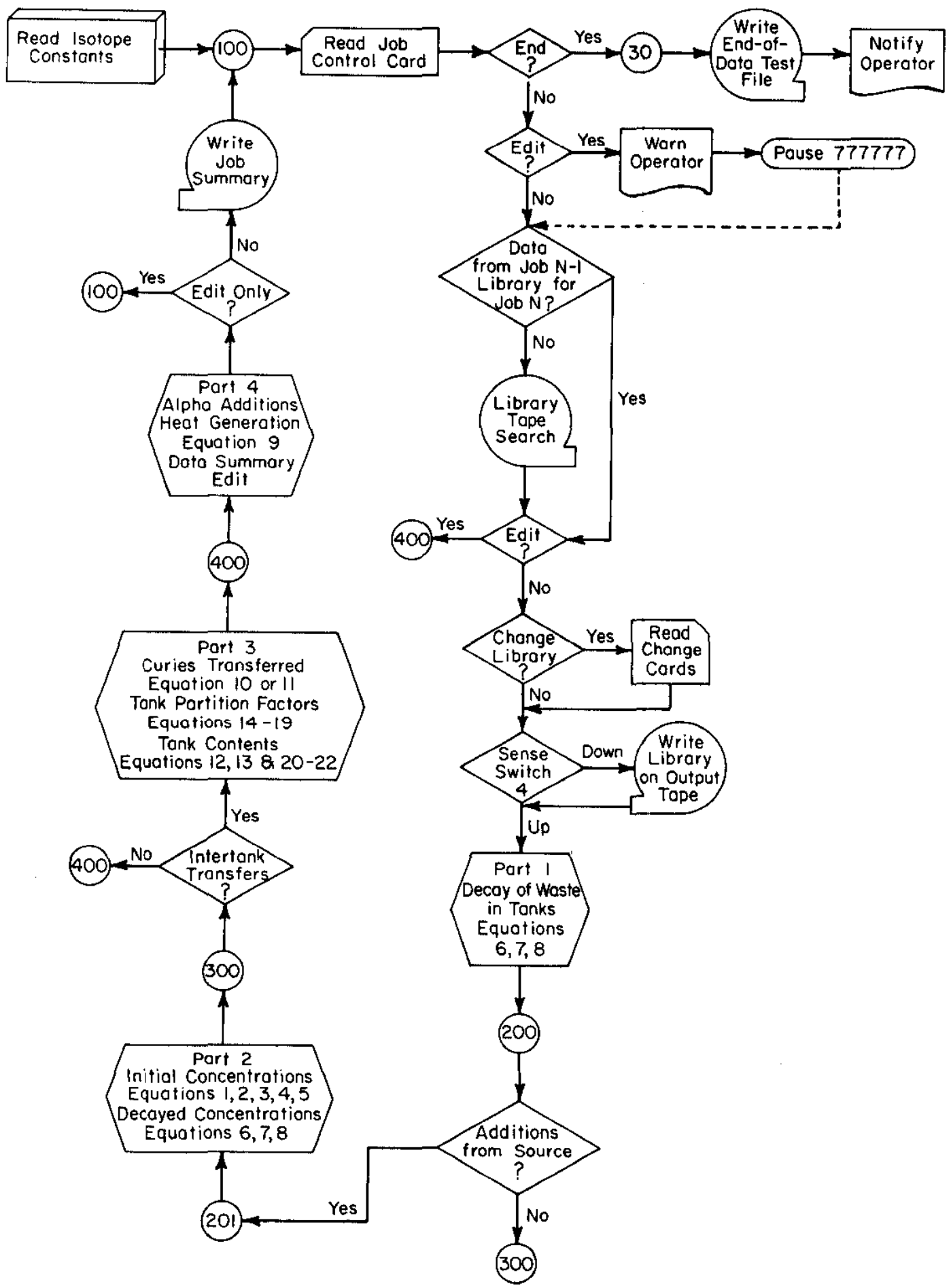

FIG. I OVER-ALL FLOW 
tank partition factors. The file number for the current job is obtained by adding 1 to the starting file number (from the control card); this file number and the current data summary are written on the library tape as the starting file for the next job.

In the use of TAFI-II, care must be exercised in the sequencing of jobs. The job sequence and the transfers in a job must be in actual time sequence. At the end of a job or a set of jobs, if more than one is run at a time, the main program writes a dummy file to signal endof-data. Because of this, care must be exercised in the use of the Edit option so that a good file will not be destroyed. At the end of each job, the main program writes a summary sheet that contains the file number and date that are required in the preparation of the control card for the next job.

\section{Main Program}

The main program reads the constants of the isotopes (half-life, yield, heat conversion factor, and name) from 13 cards (Appendix $B$, Figure 1) that immediately follow the transfer card. These constants are used for all jobs in a set, and if a constant for any isotope is to be changed the change must be made in the correct card in this deck.

The control card is read that identifies the job, the program options, and the library file for the job. The format and contents of the control card are given in Appendix B, Figure 2.

The binary library tape is then searched for the designated starting file. If changes are to be made in this file, the cards that contain the new information must follow the control card. The format of the change cards is shown in Appendix B, Figure 6. If Sense Switch 4 is DOWN the contents of the library file are written on the BCD output tape. The main program then calls subroutine PART 1 .

\section{Subroutine PART 1}

After the main program has set up the options and initial data, Subroutine PART 1 calculates the radioactive decay of the material in the tanks (from the library tape) for the specified number of days. Equations 6, 7, and 8 are used in this subroutine. If the concentration of an isotope becomes $\leqslant 10^{-5}$ curie, it is set to zero. The report written by PART 1 gives the concentration of each isotope in a tank at the beginning and the end of the decay time.

\section{Subroutine PART 2}

The additions to the system are handled by Equations 1 8 in PART 2. Each addition requires one input card that includes 1) the tank number 
to which the addition is to be added; 2) tons of uranium for Purex calculations or ${ }^{235} \mathrm{U}$ burnup for the enriched uranium calculations; 3) irradiation time, days; 4) blank for Purex calculations or power conversion factor for the enriched uranium calculations; 5) days since discharge to the end of the reporting period for this job; 6) charge identification; and 7) an option that allows the partition factors for this charge to be changed. If this option is used, the two change cards must immediately follow the addition card. These two cards should contain, in order, the partition factors for this charge. The format of the cards for additions to the system is given in Appendix $B$, Figure 3. The report for PART 2 consists of the concentration in curies and the partition factor for each isotope in each addition as it is added to the tank. The total curies for each addition and the total of all additions in a job are also reported.

\section{Subroutine PART 3}

In this subroutine the four types of intertank transfer are made with Equations 10-22. The input for this subroutine requires one card per transfer that includes (a) tank transferred from, (b) tank added to, (c) percent of supernate or siudge transferred, and (d) option number. The options are: $I=$ supernate transfer using the latest computed values for partition factors; $2=$ supernate transfer and concentration of material during transit; $3=$ sludge transfer using 1.0 - latest computed partition factors; and $4=$ sludge transfer and changed partition factors. 'l'he detailed flow chart is Figure 2. Appendix B, Figure 4, illustrates the input cards.

\section{Subroutine PART 4}

PART 4 calculates the heat generated in the tanks by each isotope by Equation 9 . It also makes additions to the alpha emitters; the input for these additions requires one card per addition with (a) tank number to which the addition is made; (b) ${ }^{238} \mathrm{U}, 10^{3} \mathrm{lb}$; (c) ${ }^{23}{ }^{5} \mathrm{U}$, $\mathrm{kg}$; (d) ${ }^{239} \mathrm{Pu}, \mathrm{kg}$; and (e) $238-239 \mathrm{Pu}$, curies, punched in this order (Appendix B, Figure 5).

The reports generated by PART 4 summarize the tank conditions (partition factors and concentration in curies) at the end of the job and gives a complete data summary of tank contents by area. The data summary is prepared for direct inclusion in a monthly report. PART 4 also updates the binary library tape at the end of each job. 


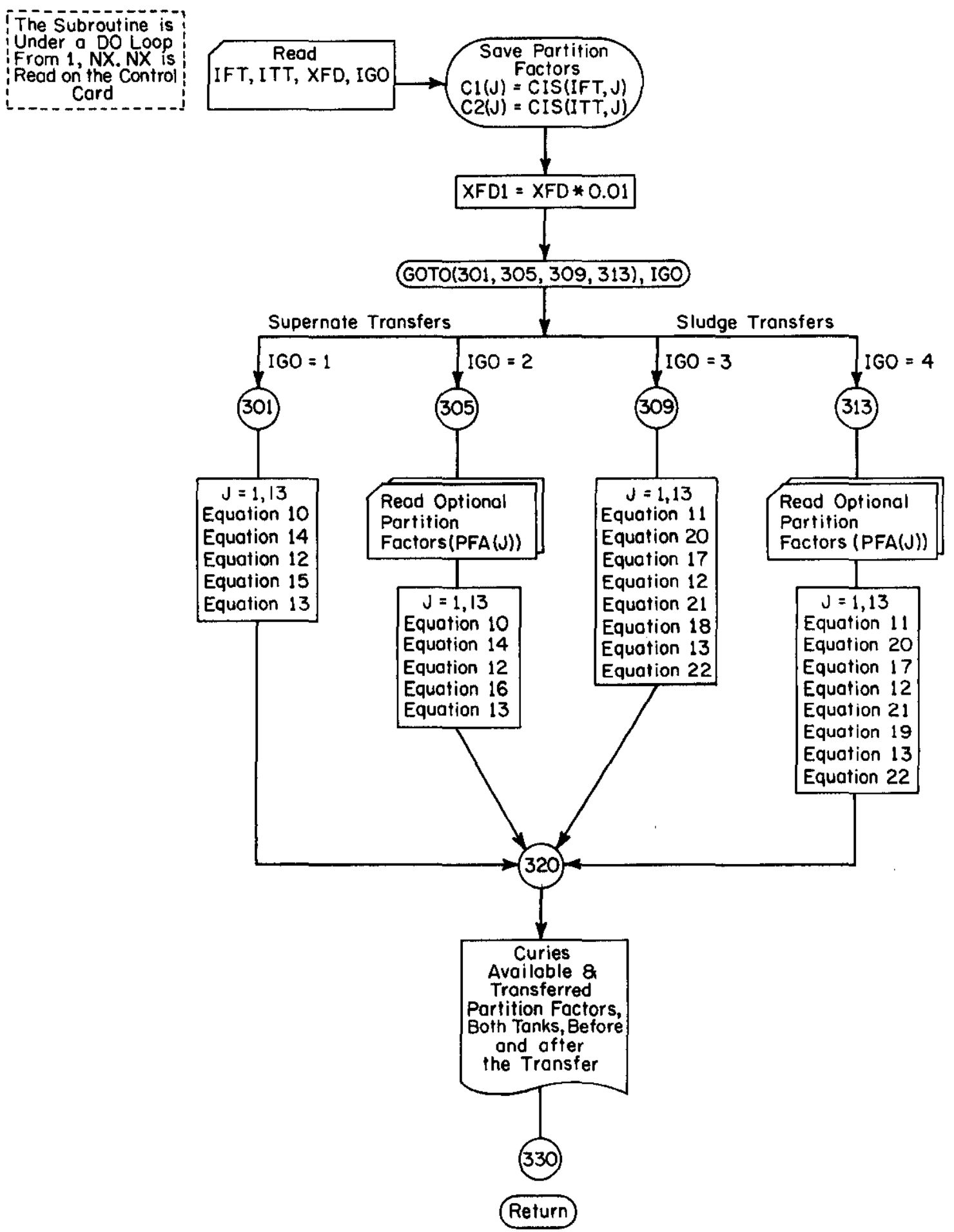

FIG. 2 SUBROUTINE PART 3 FLOW 


\section{ACKNOWLEDGMENT}

The author wishes to acknowledge the assistance and guidance provided by R. M. Shulko and D. W. Tharin, Jr. of the Waste Management Group, Works Technical Department, Savannah River Plant in the preparation of this code.

\section{REFERENCES}

1. A. N. Daniel. Underground Storage of Low-Level Radloactive Wastes at the Savannah River Plant. USAEC Report DP-478, E. I. du Pont de Nemours and Co., Wilmington, Del. (1960).

2. R. J. Christl. Storage of Radioactive Wastes in Basement Rock Beneath the Savannah River Plant. USAEC Report DP-844, E. I. du Pont de Nemours and Co., Savannah River Laboratory, Alken, S. C. (1964). 


\section{APPENDIX A - FORTRAN Listing}

TAFI IS A PROGRAM TO KEEP AN INVENTORY OF CERTAIN ISOTOPES THAT ARE FISSION PRODUCT BY-PRODUCTS OF THE SEPARATIONS PROCESSES IN THE 200 AREAS. THESE WASTE PRODUCTS ARE ACCUMULATED IN THE WASTE TANKS IN EACH AREA.

TAFI-II IS DIVIDEC INTO THE MAIN PRCGRAM AND FOUR SUBRDUTINES. THE MAIN PROGRAM READS THE IDENT. AND OPTIONS ANO SETS UP THE TANK LIBRARY DATA AND THE CONSTANTS FOR EACH ISOTOPE TO BE USED BY THE OTHER PARTS OF THE CODE.

PART 1 DECAYS THE MATERIAL IN THE TANKS FCR DOT DAYS AND WRITES THE REPORT FOR CURIES IN THE TANKS REFORE AND AFTER DECAY.

PART 2 CALCULATES THE ISOTOPIC CONTENTS DF AND ADJUSTS THE PARTITION FACTORS FOR ANY MATERIAL ADDED TO THE SYSTFM DURING THIS PERIOD OF TINE.

PART 3 HANDLES THE INTERTANK TRANSFERS BY CALCULATING THE FRACTION TRANSFERED AND RECALCULATING THE PARTITION FACTORS FUR THE TANKS INVOLVED IN THE TRANSFERS.

PART 4 MAKES THE DDOITIONS TO THE ALPHA EMITTERS, CALCULATES

THE HEAT GENERATEC IN EACH TANK AND WRITES THE FINAL DATA SUMMARY FOR BOTH AREAS.

DIMENSION TLIB $(34,13), C I S(34,13), C U R E(34,13), A H L(13), Y L D(13)$, TAFI IAHC (13), AOSS $(34,4)$, PFVI 13$), P F A(13), C U R A(13), P M(13)$ DUM2 (13),

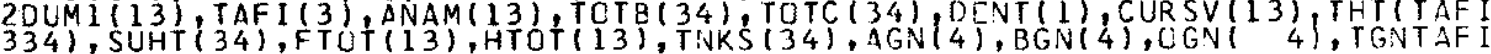

$\mathrm{C}$ $4(4)$, ASO (13)

COMMON CURE, TLIB, CI S, PFN, IPG, AHL, YLD, AHC, TAFI, ANAM, DDT, NC, NL, NX,

C

IAOSS,LIB, ILS, DUML, DUM2, NTOUT, NFI, NF2:NTLIB, DA 2, YR2, TMTZ

CALL EFM

DO $6 \quad I=1,34$

DO $5, j=1,13$

TL I $B(I, J)=0,0$

CIS $(I, j)=0.0$

CLRE $(I, J)=0.0$

5 AOSS $(I, J)=0.0$

6 CONTINUE

NTLIB $=4$

NTOUT $=10$

$I P G=0$

$N F 2=0$

REWIND NTLIB

CONSTANTS FOR EACF, ISOTOPE AND ISOTOPE NAME

AHL = HALF-LIFE, DAYS

YLD = YIELD, FRACIIONAL PERCENT

$A H C=$ HEAT CONVERSION FACTOR

PFN = NORMAL PARTIIION FACTOR, FRACTION IN SUPERNATE

ANAM = ISOTOPE NAME

$\frac{1}{2}$ DOEA $2 J=1,13$

READ IDENTIFICATICN AND OPTICNS

TAFI IDENTIFICATION

DOT - DAYS TO DECAY THE TANKS

NFI, YRl, YMTI, DAl - FILE NUMEER, YEAR, MUNTH, DAY TO BE USEO AS

THE START FOR THIS JOB

YR2, TMT2, DA2 IYEAR, MONTH, DAY OF THIS JOB

ILB' - NUMBER OF CHANGES TO CURIES IN TANKS (TLIB)

ICS - NUMBER OF CTANGES TO TANK PARTITION FACTCRS (CIS)

ILS - NUMBER OF CLANGES TO ALPHA EMITTERS (AOSS)

NC - NUMBER OF CIARGES ADDED TO SYSTEM FROM SOURCE

NX - NUMBER OF INTERTANK TRANSFERS

NL - NUMBER OF ALPHA EMITTER LDSSES TO BE ADDED TO THE SYSTEM

TAF I

TAFI

TAF I I

LIB - O=END, 1 = READ DESIGATEDFILE FOR COMPUTING, - I = PRINT

DESIGNATED FILE, NO COMPUTING

TAF I

TAFI

TAF I

TAF I

TAF I

$T A F I$

TAF I

TAF I

$T A F I$

TAF I

TAF I

TAFI

TAFI

TAF I

TAF I

$$
-15-
$$




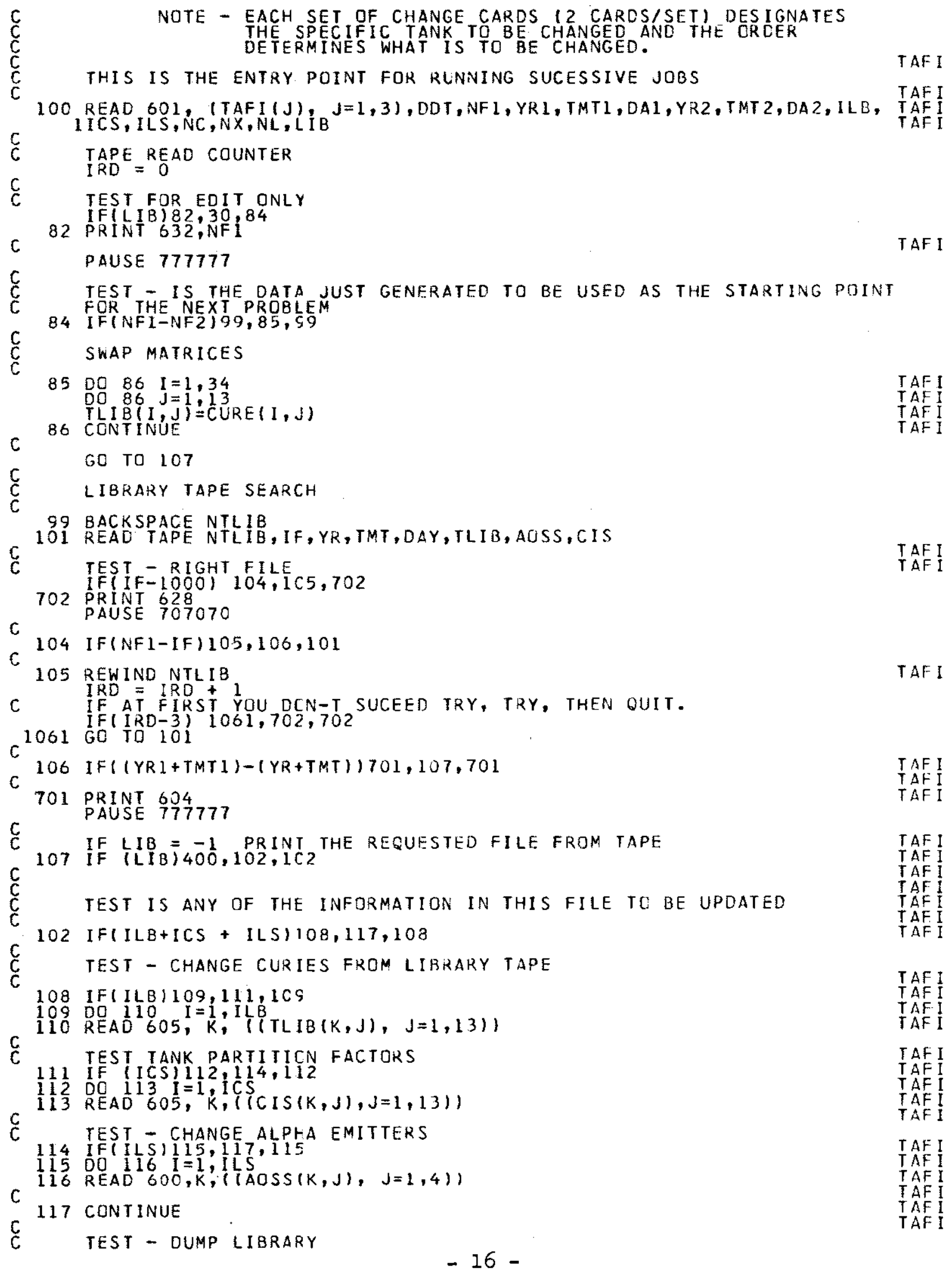


C

IF( SENSE SWITCH 4)1113,130

$I P G=I P G+1$

LINE $=0$

DO 118 I $=1,34$

120 WRI IE OUTPUT TAPE NTOUT, $630,($ TAFI $(\mathrm{J}), \mathrm{J}=1,3), 1$ PG

$119 T 1=0.0$

DO $121 \mathrm{j}=1,13$

121 CONTINUE $T I=I I+T L I B(I, J)+C I S(I, J)$

122 WRITE OUTPUT TAPE NTOUT, $631,1,((T L I B(I, J), C I S(I, J)), J=1,13)$

LINE $=L I N E+1$
123 IF I -34$) 123,124,123$
$1 F(L I N E-5) 13$

124 WRITE DUTPUT TAPE NTOUT, 609

$\angle I N E=0$

C

118 CONTINUE

c

130 CONTINUE

$\mathrm{C}$
$\mathrm{C}$
$\mathrm{C}$

CALL PART1

c

200 IF(NC) $201,300,201$

TEST - TRANSFERS (ADOITIONS) FROM SOURCE
IF(NC) 201,300,201

TAF I

c

c

$\stackrel{c}{c}$

400 CALL PART4

TEST - INTERTANK TRANSFERS

300 IF (NX) 303,400,303

303 CALL PART3

c

IF (LIB) $100,500,50 \mathrm{C}$

WRITE DUTPUT TAPE NTOUT,606, (TAFI ( J), J $=1,3)$, IPG

c IILB, ICS, ILS, NC, NX, NL

W WRITE OUTPUT TAPE NTOUT,609

CO TO 100

$\stackrel{c}{c}$

30 NEND $=1000$

WRITE TAPE NTLIB, NEND, YR2, TMT2, DA2, CURE, ADSS, CIS

REWIND NTLIB

PRINT 602

C

600 FORMAT $(12,4 E 9.4,1 A 6)$

601 FORMAT (3A6,E9.4, I3, 6F2 .0,7I2)

TAF I

TAFI

TAF I

TAFI

TAF I

TAF I

602 FORMAT 160 HOPROBLEN COMPLETED - HAVE TAPE 10 PRINTED AT 6 LINES PERTAFI

C 604 FORMAT 96 GOERROR - FILE DATE ON CARD DOES NOT, APPEAK ON LIBRARY TATAFI
IPE. END RUN. NOTIFY SUBMITCR AT ONCE. $/ 1 / \%, \%)$

$\mathrm{C}$ 605 FORMAT $(7 X, 12,6 E 9.4 /(7 E 9.4))$

C

$\mathrm{c}$

606 FORMAT (1H1, 50X, 17FSECRET WORK SHEET/ 50X,3A6,37X,5HPAGE, I2)

TAF I

C

609 FORMAT (1HO, $49 X, 17$ TEECRET WORK SHEET)

TAF I

627 FORMAT $1140,25 \mathrm{X}, 27$-SUMMARY SHEET FOR THIS JOB, $/ / 110 \mathrm{X}, 1$ \&HTANKS DECAYTAFI IED FOR , F6.0,1X,4HDAYS/10X, 12 HFILE NUMBER, I 1 , 15 HWITH TH IS DATETAFI

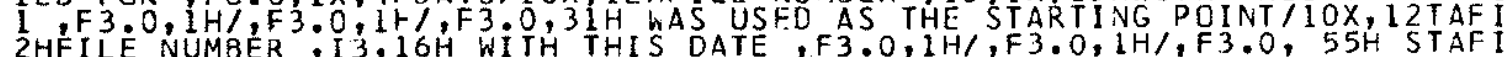
3HOULD BE USEO AS THE STARTING POINT FOR THE NEXT JOB. $110 X ; 43 \mathrm{HTHE}$ CTAFI 
C

4URIES IN THE LIBRARY FILE WERE CHANGED, I3,6H TIMES/10X, 34HTHE PARTTAFI 5ITION FACTORS WERE CHANGED, I3, 6H TIMES/ $10 X, 32$ HTHE ALPHA ENITTERS 6WERE CHANGED, I3, 6 TIMES/10X, 10HTHERE WERE, 13,28H CHARGES ADDED TOTAF I 8RE WERE,I3,33H ACEITIONS TO THE ALPHA EMITTERS /IJI TERS/IOX, IOHTHETAFI

c

8 FORMATILOTHO ERROR - FILE NUMBER RERUESTED ON CARC COES NOT APPE IAR ON THE TAPE. END RUN. NOTIFY SUBMITTOR AT ONCE./I////I/

630 FORMATI 1 H 1 , 40X, 17 HSECRET WORK SHEET/75H TANK SUMMARY AT START OF 1 JOB, CURIES AND PARTITION FACTOR FOR EACH ISOTOPE, /IOX, 3 AG,

C

631 FORMATI I , 3(8E12.4),2E12.4/1)

632 FORMAT1 3HIEDITING FILE,I4,62H BE SURE THE RING IS OUT CF THE LIQR 1ARY TAPE FOR THIS PROBLEM. $886 \mathrm{H}$ IF THIS IS THF LAST PROBLEM THE EN $2 D$ WIL BE SIGNALEC BY A SELEC ON THE LI BRARY TAPE.

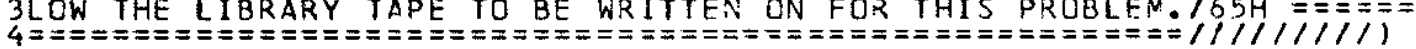
END $(2,0,0,0,0)$

$c$
$c$
$c$
$c$
$c$
$c$

PART 1

TAFI

$c$
$c$
$c$
$C$
$c$
$c$
$c$

THE LIBRARY MATERIAL HAS BEEN BROUGHT UP-TO-DATE, NOW THE MATERIALTAFI IN THE TANKS IS TC BE DECAYFD FOR THE SPECIFIED NUMBER OF DAYS IAFI SUBROUTINE PARTI

TAFI

DIMENSION TLIB $(34,13), C I S(34,13)$, CURE $(34,13)$, AHL $(13), Y L D(13)$, IAHC (13), AOSS (34,4), PFN (13), PFA1 (13), CURA (13), PM(13), DUM2 (13), TAFI 2DUMI (13), TAFI (3), ANAM(13), TCTE (34), TOTC (34), DENT (1), CURSV (13), THT (TAFI $334)$, SUH (34), FTOT(13), HTOT(13), TNKS $(34)$, AGN $\{4), B G N(4)$, OGN 4 , TGNTAFI

$c$ COMMON CURE, TLIB, CIS, PFN,IPG, AHL, YLD, AHC, TAFI, ANAM, ODT, NC, NL, NX,

c DOUBLE DO I = TANK INDEX ANO $J$ = ISOTOPE INDEX

120 DO $139 \mathrm{I}=1,34$

C M-CALCULATION FOR MOTHER ISOTOPE STATEMENT 131

C D-CALCULATION FCR DAUGHTER ISOTOPE STATEMENT 132 OR 133

C GO $\operatorname{TO}\left(1 \frac{1}{3} 1,1 \frac{2}{3} 1,13 \frac{3}{32}, 131,131,132,131,132,131,133,131,1 \frac{1}{3}, 1 \frac{1}{3} 11, \mathrm{~J}\right.$

$\mathrm{C}$

$131 S A M=.693 / A H L(J)$

CURE $(I, J)=T L I B(I, J) * E X P F(-S A M * D O T)$

C

IFICURE $(1, J)-1: E-6) 137,137,138$

$132 S A M=.693 / \mathrm{AHL}(J-1)$

$S A D=.693 / A H L(J)$

$Z 1 D=S A D /(S A D-S A M)$

CURE $(I, J)=Z 1 D *(T L I B(1, J-1) *(E X P F(-S A M * D D T)-E X P F(-S A D *$

IOCTI)

c

$133 \operatorname{CURE}(I, J)=0.92 * \operatorname{CURE}(1, J-1)$

C

IFICURE II, Ji $-1 . E-6)\{37,137,138$

137 CURE $(I, J)=0.0$

139 CONTINUE

\section{CONTINUE}

NO NEED FOR THIS REPORT IF THERE ARE NO CHANGES

IF (DDT) 145,190,145

C SUMS FOR ISOTOPES BEFORE AND AFTER DECAY

145 DO $140 \quad I=1,34$

TOT $8(1)=0.0$

DO $141 \quad J=1,13$

TAFI

TAF I

IAF I

TAF I

TAF I

TAF I

$T A F I$

TAF I

TAF I

TAF I

IAFI

TAF I

TAF I

TAF I

IAF I

TAF I I

TAF I

TAF I

TAFI

TAF I 

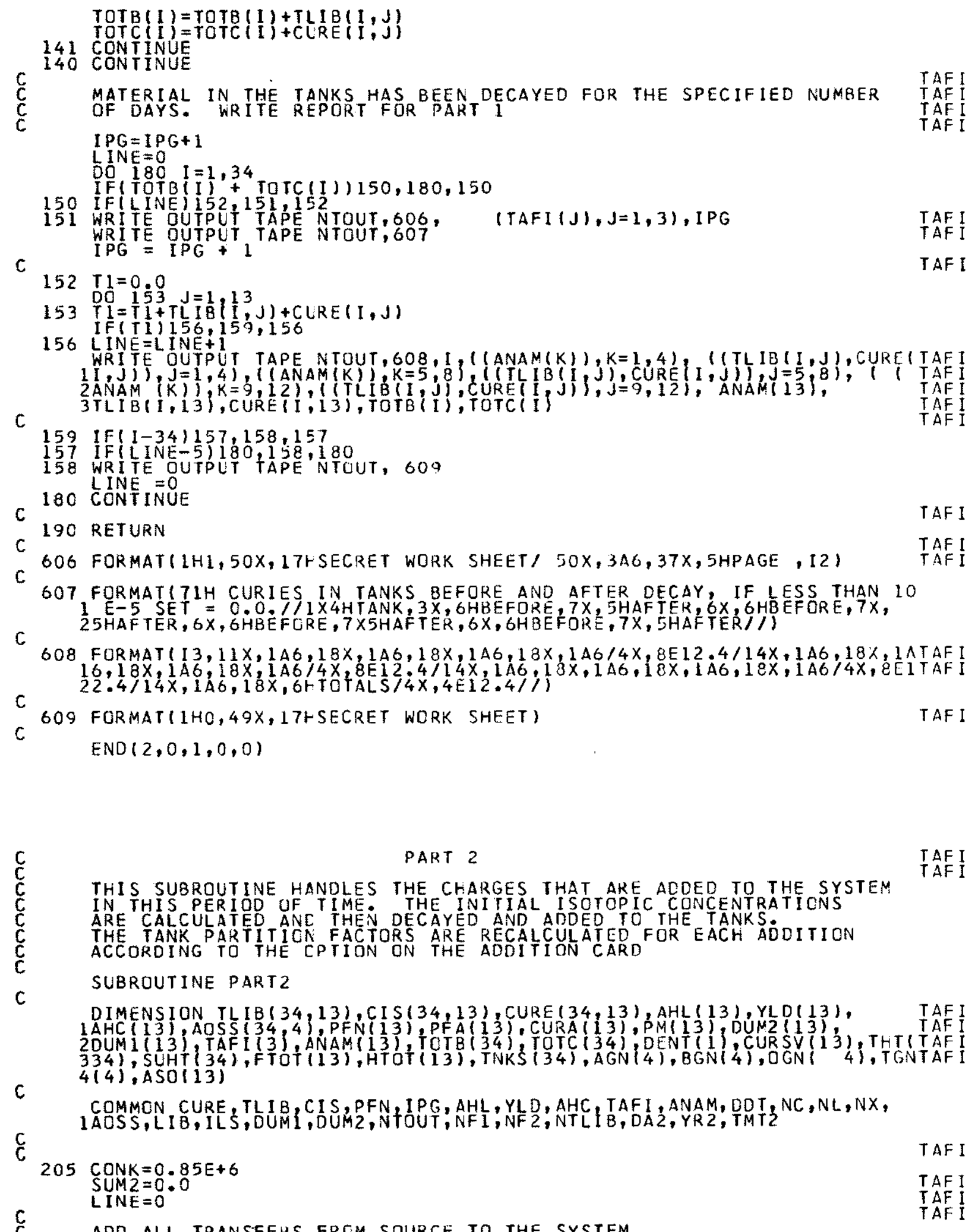

C $\quad$ ADD ALL TRANSFERS FRCM SOURCE TO THE SYSTEM 
DON $250 N T=1, N C$

REAC 610, JT, P1, P 2, P 3, P4, DSD, DENT, NML

214 DO $230 \mathrm{~J}=1,13$

$A S Q$
$C U R S V(J)=0.0$

C SAME SCHEME TO DECAY THE ISOTCPES AS THE TANK DECAY GO $\mathrm{TO}(215,215,216,215,215,216,215,216,215,217,215,216,215), \mathrm{J}$

C $\quad$ MOTHER

$\check{c}$

$S A=0.693 / A H L(J)$ CONCENTRATION AT REACTOR DISCHARGF - ASO

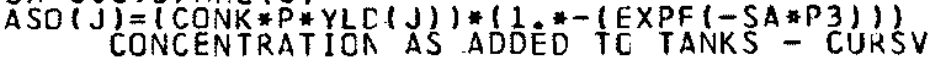

$\stackrel{C}{C}$

CURSV $(J)=A S O(J) * \operatorname{EXPF}(-S A * D S D)$

C DAUGHTER CONCENTRATICA AT REACTOR DISCHARGE

$216 S A=0.693 / A H L(J-1)$

$S B=0.693 / A H L(J)$

$Z 1=S B /(S B-S A)$

$Z 2=S A / I S B-S A$

A SO $(J)=(C O N K * P * Y L C(J)) *(Z 1 *(1,-E X P F(-S A * P 3)))-Z 2 *(1 .-E X P F(-S B$

C CONCENTRATICA AS ADDED TC TANKS

TAF I

TAF I

TAF I

TAF I

TAFI

TAF I

TAF

TAF I

IAF

TAF I

IAF

TAF I

TAF I

$T A F$

TAFI

TAF

IAF I

IAF

TAF

$T A F I$

TAF I

TAF I

TAFI

$T A F I$ CURSV $(J)=Z 1 *(A S O(J-1) *(E X P F(-S A * D S D)-E X P F(-S B * D S D)))+A S O(J) * T A F$

IEXPF(-SB*DSD)

C

217 CUR SV $(J)=0.92 * \operatorname{CURSV}(J-1)$

C

IFICURSVIJ)i229,230,230

229 CUR SV $(J)=0.0$

$c$
$\mathrm{C}$
$\mathrm{C}$
$\mathrm{C}$
$\mathrm{C}$

CALCULATE NEW PARTITION FACTCRS FOR EACH ISOTOPE

AND ADD THE ISOTCPES TO THE DESIGNATED TANK USEO TO RECALCULATE THE PARTITION FACTORS FOR THE TANK

TANK PARTITION FACTCRS ARE CALLED CIS

NORMAL PARTITION FACTORS FUR EACH CHARGE ARE CALLED PFN

IF(NML) $240,231,24 \mathrm{C}$

c

$23100235 \mathrm{~J}=1,13$ ISV(J)

SUM $1=$ SUM $1+$ CURSV $(J)$

$\stackrel{c}{\mathrm{C}}$

GURE $(J T, J)=C U R E(J T, J)+C U R S V(J)$

240 READ 605, NG, (PFA (J), $J=1,13$ )

$N G=0$

DD $241, J=1,13$ IS $(J, J)=1$ CIS $J, J) * C U R E(J T, J)+C U R S V(J) * P F A(J)) /(C U R E(J T, J)+C(U R S$

$1 \mathrm{~V}(\mathrm{~J})$

SUMI = SUM $1+$ CURSV $(J)$

241 CURE $(J T, j)=C U R E(J T, J)+C U R S V(J)$

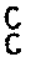

245 SUM2 $=$ SUM $2+$ SUM1

$c$
$c$
$c$

WRITE THE REPORT FOR THE TRANSFERS FROM SOURCE

PRINT HEADING 
IF(LINE) $247,246,247$

246 I $P G=I P G+I$

WRITE OUTPUT TAPE NTOUT,606, (TAFI(1), I=1,3), IPG

$\stackrel{c}{c}$ WRITE OUTPUT TAPE NTOUT;611

247 WRITE OUTPUT TAPE NTOUT, 613,JI,P1,P2,P3,P4,DSD, DENT, NML, P

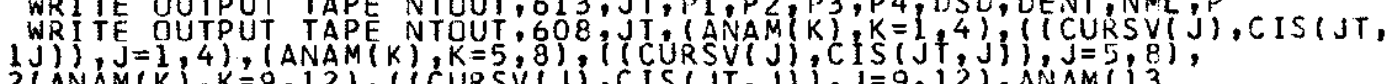

$c$ 2 (ANAM $(K), K=9,12),(1 C U R S V(J), C$ IS $(J T, J)\}, j=9,12)$, ANAM( 3 3), CURSV $(13), C I S(J T, 13)$, SUML, SUM 2

LINE $=L I N E+1$

IFINT-NCI248,249,248

249 WRITE DUTPUT TAPE'NTOUT, 609

250 CONTINUE

$\mathrm{C}$

260 RETURN

C

$c$

605 FORMAT $(7 X, 12,6 E 9.4 /(7 E 9.4))$

608 FORMATI $3,11 \times, 1 A 6,18 \times, 1 A 6,18 \times, 1 A 6,18 \times, 1$ A6/4X,8E12,4/14X,1A6, $18 X$, 1ATAF $16,18 X, 1 A 6,18 X, 1 A 6 / 4 X, 8 E 12: 4 / 14 x, 1 A 6,1 B X, 1 A 6,18 X, 1 A 6,18 X, 1 A 6 / 4 X, 8 E 1 T A F$

C

609 FORMAT(1HO, 49X,17HSECRET WORK SHEFT)

TAF I

610 FORMAT $(12,5 E 9.4,1 A 6,12)$

TAF I

611 FORMAT $139 X, 21$ HTRANSFERS FROM SOURCE/5H TANK, $3 X, 6 H C U R I E S, 3 X, 11$ HOARTTAF

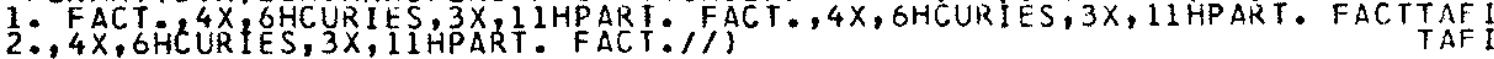

C

613 FORMAT(6HOINPUT $1 X, 12,5(1 X, E 9.4), 1 X, 1 A 6,1 X, 11$ HOPTION NO. $11,1 X, 3 H P=$ TAFI C END $(2,0,0,0,0)$

C

PART 3

TAF I

SUBROUTINE PART 3

C

DIMENSION TLIB $(34,13), C I S(34,13), C U R E(34,13)$, AHL $(13), Y L D(13)$,

TAF I IAHC (13) AOSS $(34,4$, PFN (13), PFA (13), CURA (13), PM( 13$)$ DUM2 (13), TAF 2DUM I ( 3 , TAF I 3 , ANAM(13) TOTE $4(4)$, $S$ ( 34$), F T O T(13), H T O T(13)$, TNKS(34), AGN(4), RGN(4), OGN 4), TRN TAF $4(4)$ A ASO $(13)$

C

COMMON CURE, TLIB, CIS, PFN, IPG, AHL, YLD, AHC, TAFI, ANAM, DDT, NC, NL, NX,

$c$
$c$
$c$
$c$
$c$
$c$
$c$
$c$
$c$
$c$
$c$
$c$
$c$
$c$
$c$ IAOSS,LIB,ILS, DUMI, DUMZ, NTOUT,NFI, NF $2, N T L I B, D A 3, Y R 2, T M T 2$

THIS PART OF THE CODE HANDLES THE INTERTANK TRANSFERS

TAF I

THE CALCULATIONS ARE FOR THE FRACTION TRANSFERED (PM)

TAF 1

AND THE RECALCULATION OF THE TANK PARTITICN FACTORS (CIS)

TAFI

THE FOUR OPTIONS CN TYPE OF TRANSFER ARE IGO = I SUPERAATE TRANSFER WITH CALCULATFO PARTITION FACTORS

IGO $=\frac{1}{2}$ SUPERAATE TRANSFER WITH OPTIONAL PARTITION FACTORS

IGO $=3$ SLUDGE TRANSFER WITH CALCULATEO PARTITICN FACTORS

IGO $=4$ SLUDGE TRANSFER WIITH OPTIONAL PARTITION FACTORS

IF IGO $=3$ OR 4 , CIS IS RECALCULATEO FROM $(1.0$ - PARTITION FACTOR)

LINE=0

DO $330 \quad N T=1, N X$

SUM $1=0.0$

READ $612, I F T, I T T ; X F D, I G O$ 
C PFDI=XFD*OAOI

TAF I

DO $3301 \mathrm{~J}=1,13$

$C(1)=0.0$

$C 2(J)=0.0$

C

C $\frac{1}{2}(J)=C I S(I F I, J)$

$c$
$C$
$C$
$C$

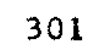

301

TAF I

SUPERNATE TRANSFER

$\begin{array}{ll}C & \text { SUPERNATE TRANSFER } \\ C & \text { TRANSFER COMPUTEC ON THE BASIS OF THE LATEST COMPUTED VALUES OF } \\ C & \text { THE TANK PARTITICN FACTORS }\end{array}$

TAF I

TAF I

TAFI

$\operatorname{DUM} 1(\mathrm{~J}) \mathrm{j}=1,13$

DUM2 $(J)=0: 0$

$P M(J)=0$.

$P M(J)=X F D i * C U R E(I F T, J) * C I S(I F T, J)$

IF(PM (J)) 302,302,303

303

DUMI I J $=$ SUM L DURE IFT, J)

SUM $2=S U M 2+P M(J)$

$\operatorname{CIS}(I F T, J)=(\operatorname{CIS}(I F T, J) * \operatorname{CURE}(I F T, J)-P M(J)) /(C U R E(I F T, J)-P M(J$

C

C
SUBTRACT FROM TANK IFT
CURE IIFT, J)=CURE $(I F T, J)-P M(J)$

C ADD TO TANK ITT

DUM $2(j)=C U R E(T T T, J)$

CIS (ITT,J) = (CIS IIT,J)*CURE (ITT,J)+PM(J))/(CURE(ITT,J)+PM(J))

CURE $(I T T, J)=\operatorname{CURE}(I T T, J)+\operatorname{PN}(J)$

$c$
$c$
$c$

302 CONTINUE

TAFI

SUPERNATE TRANSFER WITH OPTIONAL PARTITION FACTORS

305 READ $605, N G,(P F A(J), J=1,13)$

DQ $306 \mathrm{~J}=1,13$

DUMI (J) $=0.0$

DUM 2 (J) $=0.0$

$P M(J)=X F D I * C U R E(I F T, J) * C I S(I F T, J)$

307 IF(PM(J)) $306,306,307$

DUMLI J) SUMi+DUREIIFT, J)

SUM $2=S U M 2+P M(J)$ T

1) IS $(I F T, J)=$ (CISIFT, J) * CURE(IFT,J) - PM(J))/(CURE(HFT,J)-PN(J

C

RE (IFT, J) $=\operatorname{CURE}($ IFT, J) $-P M(J)$

TAFI

CIS $(I T T, J)=(C I S(I T T, J) * \operatorname{CURE}(I T T, J)+P M(J) * P F A(J)) /(C U R E(I T T, J)$

$1+P M(j))$

DUM $2(J)=C U R E(I T T, J)$

306

CURE $(I T T, J)=\operatorname{CURE}(I T T, J)+\operatorname{PN}(J)$

$c$
$c$
$C$
$C$
$c$
$C$

GO TO 320

SLUDGE TRANSFER WITH COMPUTED PARTITION FACTORS

ALPHA EMITTERS (PL+U ISOTOPES) ARE TRANSFERED WITH THE SLUDGE

TAF I

TAFI

TATI

TAF I

TAF I

TAF I

DO $310 \mathrm{~J}=1,13$

$P M(J)=0.0$

DUM $2(J)=0.0$

$\mathrm{DUM} 2(\mathrm{~J})=(1+\mathrm{C}, \dot{0}$

PM $(J)=C U R E(I F Y, J) * A * X F D I$

IF (PM J J) $310,31 \mathrm{C}, 311$

311 DUMI J = CURE(IFT,J)

SUM1 $=$ SUM1 + DUMI $(J)$

$\operatorname{SUM} 2=\operatorname{SUM} 2+P M(J)$

CIS (IFT,J) $=$ (CIS (IFT,J)*CURE (IFT,J))/(CURE $(I F T, J)-P M(J))$

C

CIS $(I T T, J)=(C I S(I T T, J) \geqslant \operatorname{CURE}(I T T, J)) /(\operatorname{CURE}(I T T, J)+P M(J))$

CURE (ITT,J)= CURE(ITT,J) + PN(J)

TAFI
TAFI
TAF I

TAF I I

TAFI

IAF I 


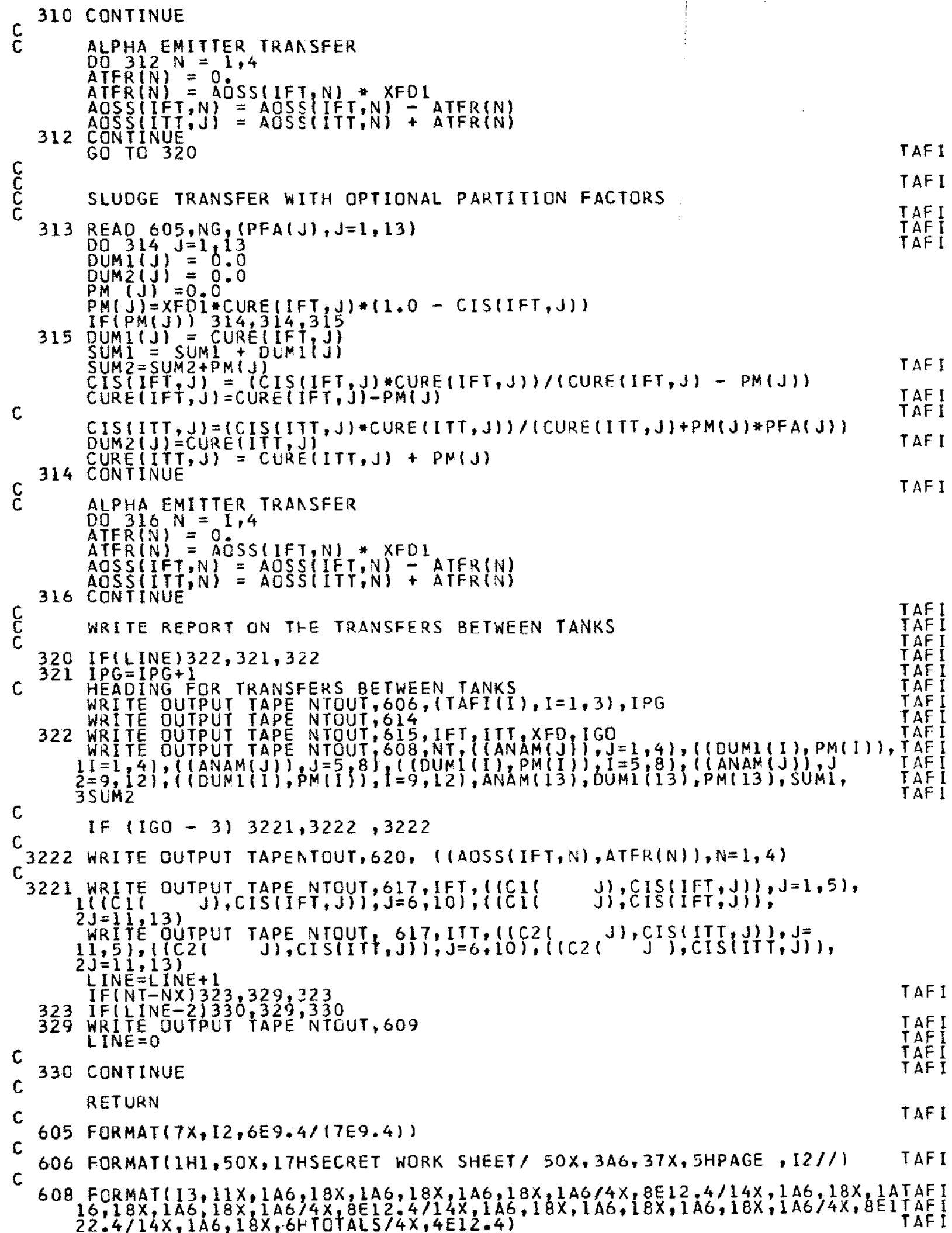


C

C

609 FORMAT (1HO,49X,17HSECRET WORK SHEET)

TAF I

C

614 FORMATI $40 X, 19 H I N T E R T A N K$ TRANSFERS $/ 6 X, 9 H A Y A I L A B L E, 3 X, 1$ OHTRANSFERED, TAFI

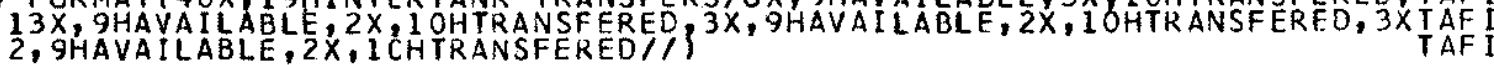

C

615 FORMAT I $17 H O I N P U T$ CATA, FROM, 13,1X,3HTO, I 2, 1X14HPERCENT MOVED,F6. TAFI

C

617 FORMAT 135 HOPARTITION FACTOR CHANGES FOR TANK I $2,1 \times, 42 H E A C H$ ISOTOPE 1 BEFORE AND AFTER THE TRANSFER/ 4X,8E12.4/4X,8E $12.4 / 4 \mathrm{X}, 8 \mathrm{E} 12.4$

C

C

620 FORMATI16H ALPHA TRANSFER, BE $12.4 / / 1$

END $(2,0,0,0,0)$

$\stackrel{C}{C}$

PART 4

TAF I

SUBROUTINE PART 4

C

DIMENSION TLIB $(34,13), C I S(34,13)$, CURE $(34,13)$ AHL $(13), Y L D(13)$,

TAF I $1 A H C(13)$ AOSS $(34,4\}$, PFN $(13), P F A(13), C U R A(13), P M(13)$, OUM2(13), TAF 2DUMI(13), TAFI $(3)^{4}$, ANAM(13), TOTB $(34)$; TOTC $(34)$ DENTI $\}$, CURSV(13), THT(TAFI 334), SUHT(34), FTOT(I3), HTOT (13), TNKS $(34)$, AGN $(4), B G N(4), O G N(4), T G N T A F I$ $4(4)$, ASO $(13)$

C A $(34,13), 19(34,13)$ COMMON CURE, TLIB, CIS,PFN,IPG, AHL, YLD, AHC, TAFI, ANAM, DDT, NC, NL, NX,
IAOSS, LIB, ILS, OUMI, DUMZ, NTOUT, NFI, NF2, NTLIB, DA2, YR2, TMTZ

$C$
$C$
$c$
$C$
$C$
$C$
$C$
$C$
$c$

THIS PART OF THE PROGRAM CALCULATES THE HEAT GENERATED IN EACH

TANK AND SPLITS THE HEAT INTO SLUDGE AND SUPERNATE ACCORDING TO

THE COMPUTED PAKTITION FACTORS IT ALSO WRITES THE FINAL REPORT

FOR THE MONTH ANO UPDATES THE LIBRARY TAPE. IF IT IS NECESSARY
TO ADO TO THE ALPFA EMITTERS IT IS DONE IN THIS PART OF THE CODE

TAF I

TAF I

TAF I

TAF I

TO ADO TO THE. ALPHA EMITTERS IT IS DONE IN THIS PART OF THE CODE

TAF I

C LINE $=$ ADOITIONS TO ALPHA ENITTERS

4501 DO 4502 IL $=1, N L$

$\left.4503 \mathrm{OGN}^{4503} \mathrm{~J}\right)=0 . \mathrm{C}^{4}$

$c$
$c$
$c$
$c$
$c$
$c$

\title{
1 - TANK NUMBER
}

OGN (1) - U-238, IrOUS. LB.

OGN $(2)=U-235, K G$

OGN $(3)=P U-239, K G$.

READ $618, I,(O G N(J), J=1,4)$

DOS $4502, J)=1,4$ (I, J) $=A O S S(I, J)+O G N(J)$

TAF I

CONTINUE

)

PLACE LIBRARY DATA IN CURE MATRIX FOR PRINTING

TAF I

4505 PLACE LIBRARY DATA IN

4100 DO 4110 I $=1,34$

DO $4110 j=1,13$

$4110 \operatorname{CURE}(\mathrm{I}, \mathrm{J})=\operatorname{TLIB}(I, \mathrm{~J})$

C CALCULATE HEAT IN EACH TANK

4500 DO 410 I $=1,34$

THT $($ I) $=0.0$

SUHT (I) $=0.0$

C CALCULATION OF ISCTUPIC CONTRIBUTIONS TO HEATS

TQ $(1, J)=0.0$.

$T g(I, J)=0.0$ 


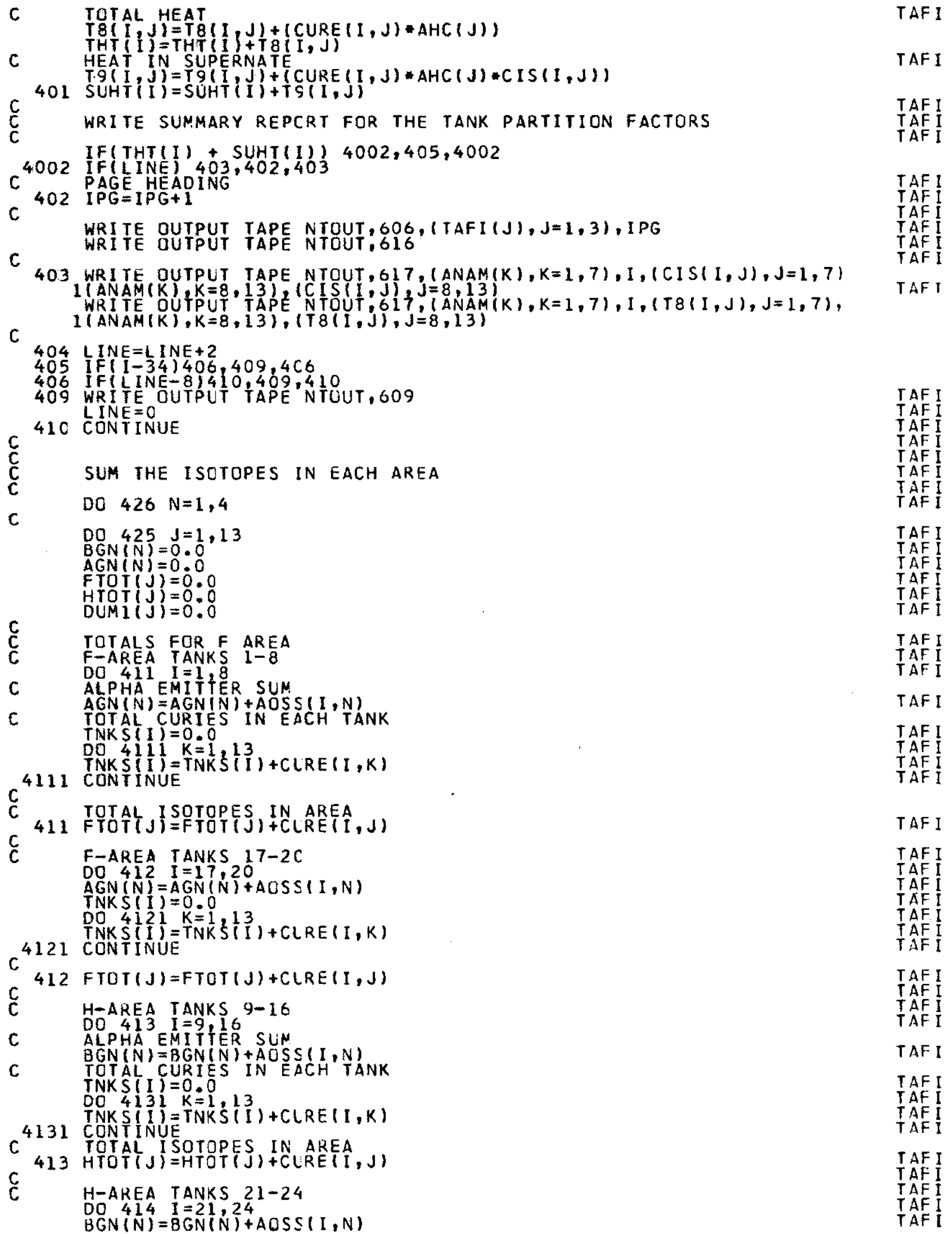




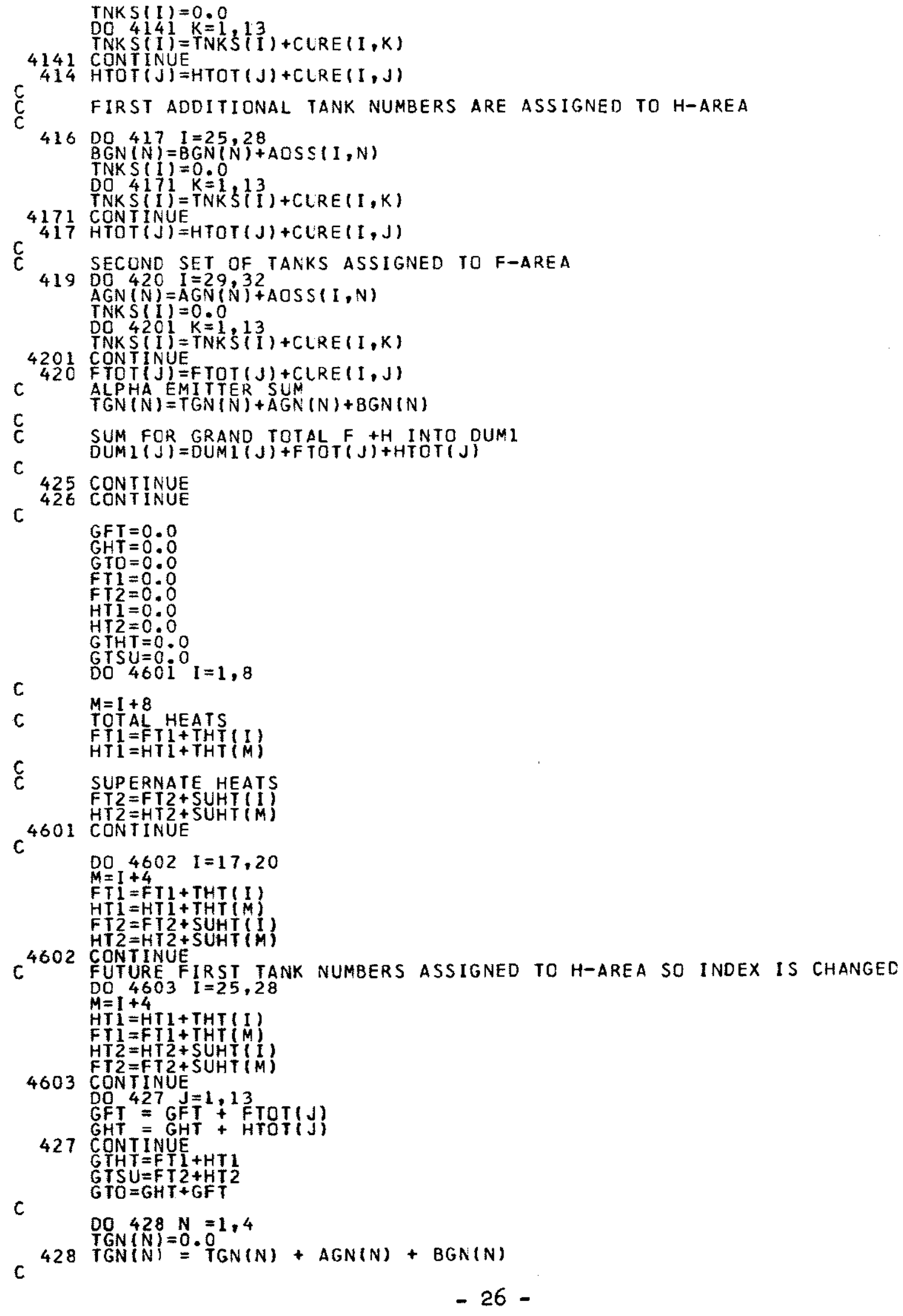

TAF

TAF I

TAF I 
$C$
$C$
$C$

C

WRITE THE FINAL REPORT FOR THIS JOB

TAFI

FIRST PAGE

$I P G=I P G+1$

WRITE OUTPUT TAPE NTOUT, $619,[P G,(T A F I(J), J=1,3)$ WRITE OUTPUT 430 WRI $\int_{\text {DO }}^{4}$ OUTPUT TAPE NTOUT, $621, \mathrm{I},(\operatorname{CURE}(\mathrm{I}, \mathrm{J}), \mathrm{J}=1,8)$

c

431 WRI TE DUTPUT TAPE NTOUT, 621, I, (CURE $(I, J), J=1,8$ )

MORE TANKS IN F-AREA

432 DQ $433 \quad I=29,32$

TEST FOR PRINTING OF ADDITIONAL TANKS

$T 1=0.0$

DO $4333 \mathrm{~J}=1,13$

$4333 T 1=T 1+C U R E(I, J)$

4334 WR TI $4334,433,4334$ TOUT,621, I, (CURE $(I, J), J=1,8)$

433 CONTINUE

C

TOTALS OF EACH ISCTOPE IN F-AREA

$\mathrm{C}$

434 WRITE DUTPUT TAPE NTOUT, 622, (FTOT $(J), J=1,8$ )

IS THE DEEP MINE CAVERN IN USE

$F D M=0.0$

435 DO $435 \mathrm{~F}=1,13$

IF(FDM) $436,440,436$

436 WRITE QUTPUT TAPE NTOUT, $625,(\operatorname{CURE}(33, \mathrm{~J}), \mathrm{J}=1,8)$

H-AREA TANKS

441 WRITE OUTPÚT TAPE NTOUT, 621, I, (CURE $(1, \mathrm{~J}), \mathrm{J}=1,8$ )

442 WRITE DUTPUT ${ }^{24}$ IAPE NTOUT, $621,1,(\operatorname{CURE}(\mathrm{I}, \mathrm{J}), \mathrm{J}=1,8$ )

$\stackrel{c}{c}$

MORE TANKS IN H-AREA

C 443 DO $444 \mathrm{I}=25,28$

TEST FOR PRINTING OF ADDITIONAL TANKS

$T 1=0.0$

DO $4443 \mathrm{~J}=1,13$

$4443 \mathrm{~T} 1=\mathrm{T} 1+\mathrm{CURE}(\mathrm{I}, \mathrm{J})$

4444 WRITE OUTPUT TAPE NTOUT, 621, I, (CURE (I, J); J 1,8 )

C

444 CONTINUE

C TOTALS FOR H-AREA TANKS

C

445 WRITE OUTPUT TAPE NTOUT,622, (HTOT $(\mathrm{J}), \mathrm{J}=1,8)$

WRITE OUTPUT TAPE NTOUT, $622,($ DUMI $(J), J=1,8)$

$\mathrm{HDM}=0.0$

DO $446 \mathrm{~J}=1,13$

446 HDM $=$ HDM+CURE $(34, \mathrm{~J})$

IF (HDM) $447,450,447$

447 WRITE QUTPUT TAPE NTOUT, $625,(\operatorname{CURE}(34, \mathrm{~J}), \mathrm{J}=1,8)$

C

PAGE 2 OF THE FINAL REPORT

$I P G=I P G+$

WRITE DUTPUT TAPE NTOUT,619, IPG, (TAFI $(\mathrm{J}), \mathrm{J}=1,3)$

C

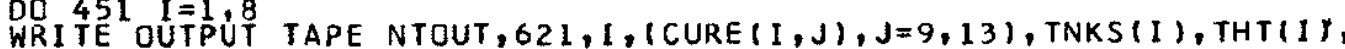
1 SUHT(I)

DO $452 \quad I=17,20$

452 WRITE OUTPUT TAPE NTOUT,621,I, (CURE $(I, J), J=9,13)$, TNKS (I), THT (I),

C ISUHT(I)

453 D0 $455 \quad I=29,32$

DO $4541 \mathrm{~J}=1,13$

TAF I

TAFI

IAF

TAF

TAF I

IAF I

TAF I

IAF

TAF I

TAF 1

TAF

TAFI

TAF I

IAF I

TAF I

TAF

$T A F 1$

TAF

TAF

TAF

TAF I

TAF I

TAF I

TAF I

TAF I

TAF I

$T A F$

TAF I

IAF

TAFI

TAF

TAF I

TAF I

TAF I

TAF

TAF I

TAF I

TAF I

$T A F I$

IAF

IAF I

TAF I

TAF I

IAF

TAF I

TAFI

TAFI

TAF I

TAF I

$T A F I$

TAF

TAF I

TAF

TAF

TAF I

TAF I

TAF I

TAFI 


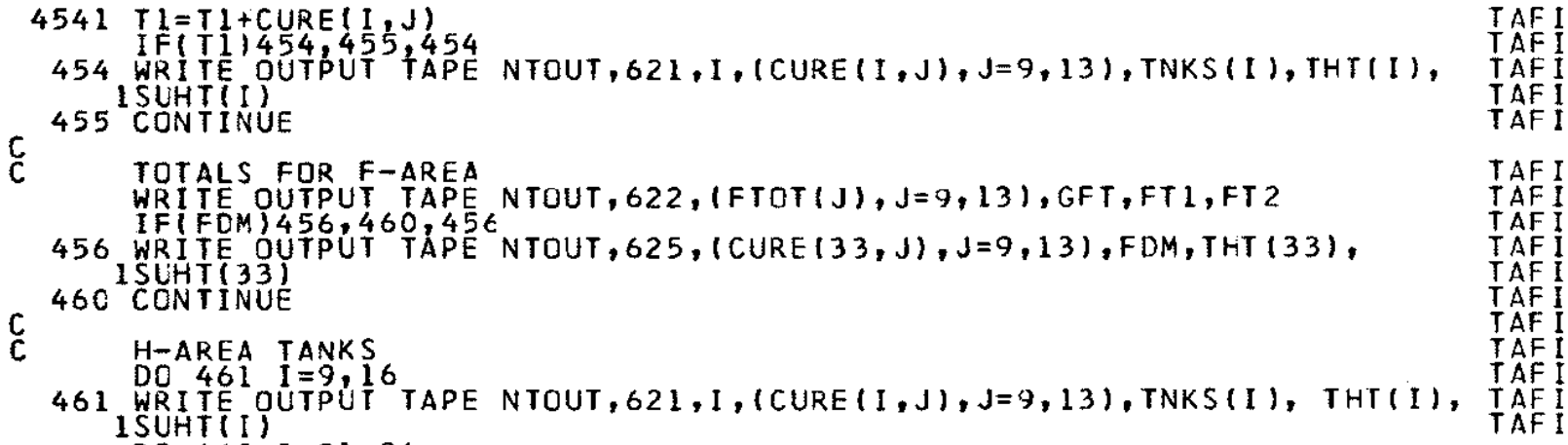




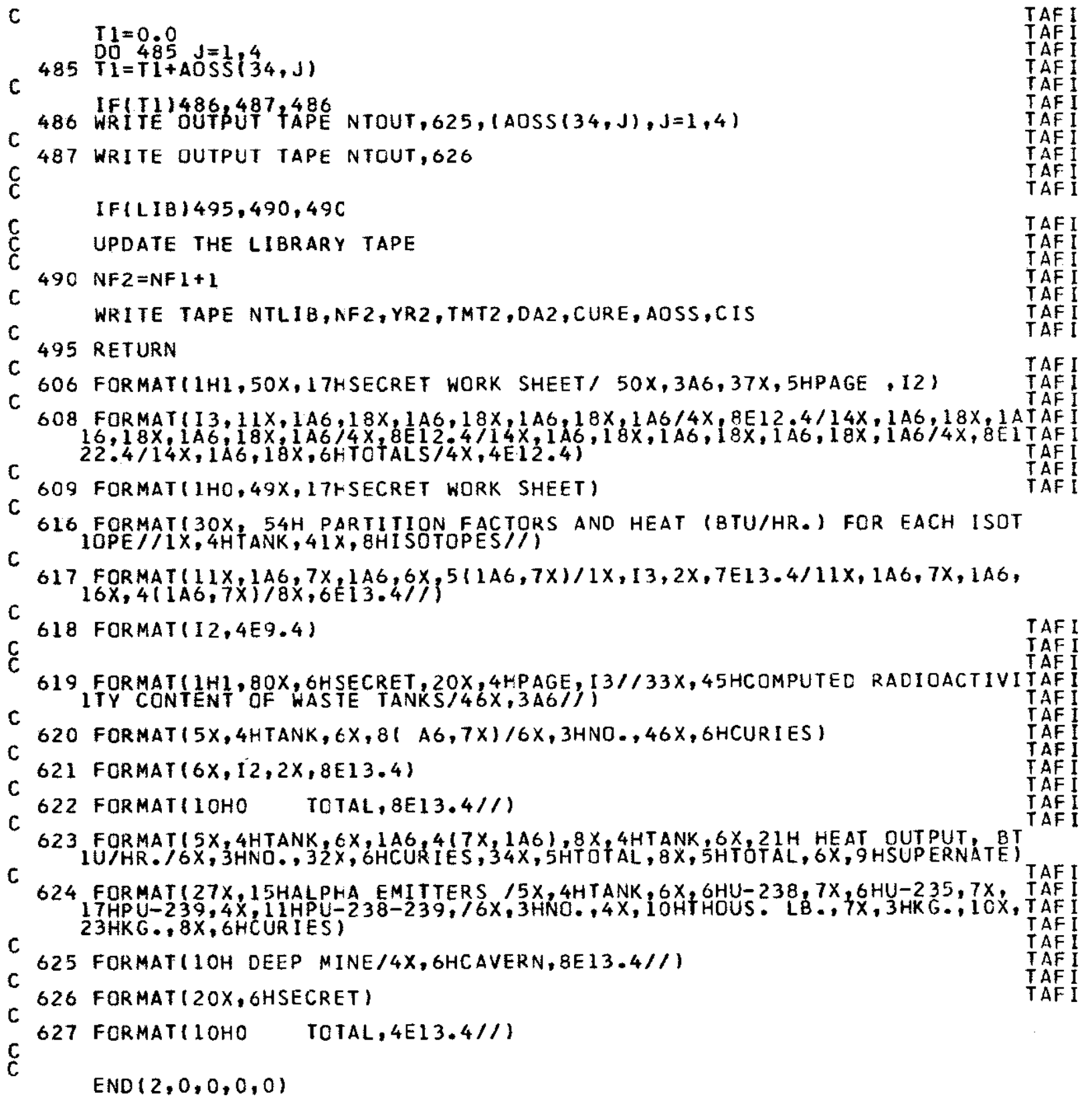




\section{APPENDIX B - Input Data Formats and Sample Problem}

The formats and contents of the input data cards are presented in the order in which they would appear in an actual job. Each job(s) requires one set of 13 Isotope Constant cards, one/isotope; a Control card for each job; and the appropriate number of data cards and/or change cards. The required order of the data deck is 1llustrated below.

\section{Doto Deck}

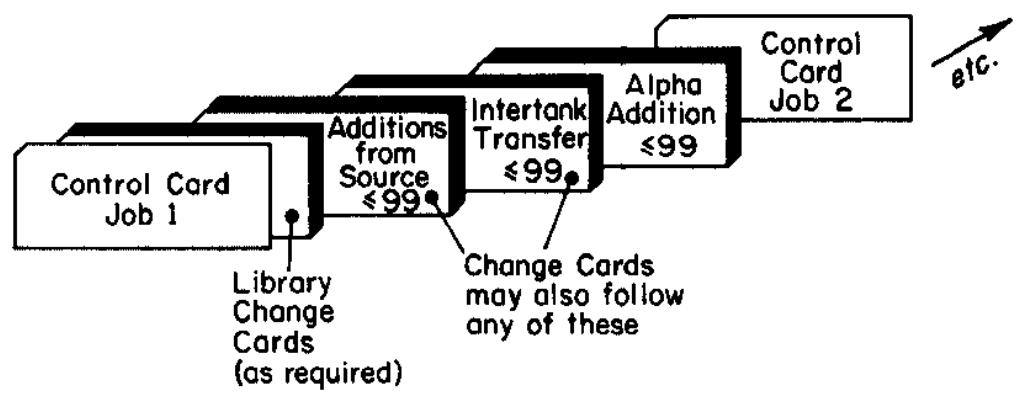

A blank Control card inaicates end-of-job(s). Isotope constant cards are not considered part of the data deck. 
FIGURE ।

Isotope Constants Card - 13 required per fob or set of jobs FØRMAT( I2, 4E9 .4, IA6)

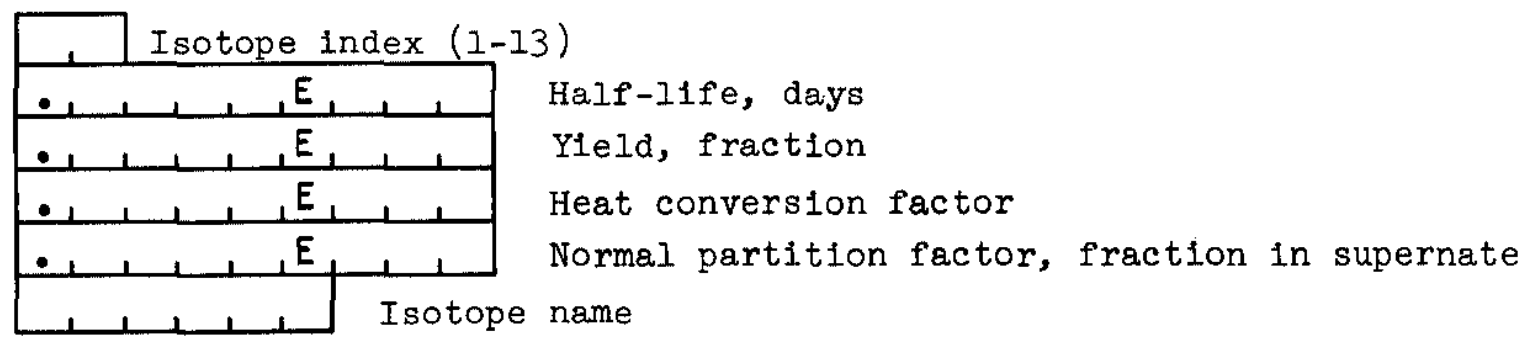

FIGURE 2

Control Card - 1 required per job

FØRMAT ( ЗАб, E9 .4 , I3, 6F2 .0,7I2 )

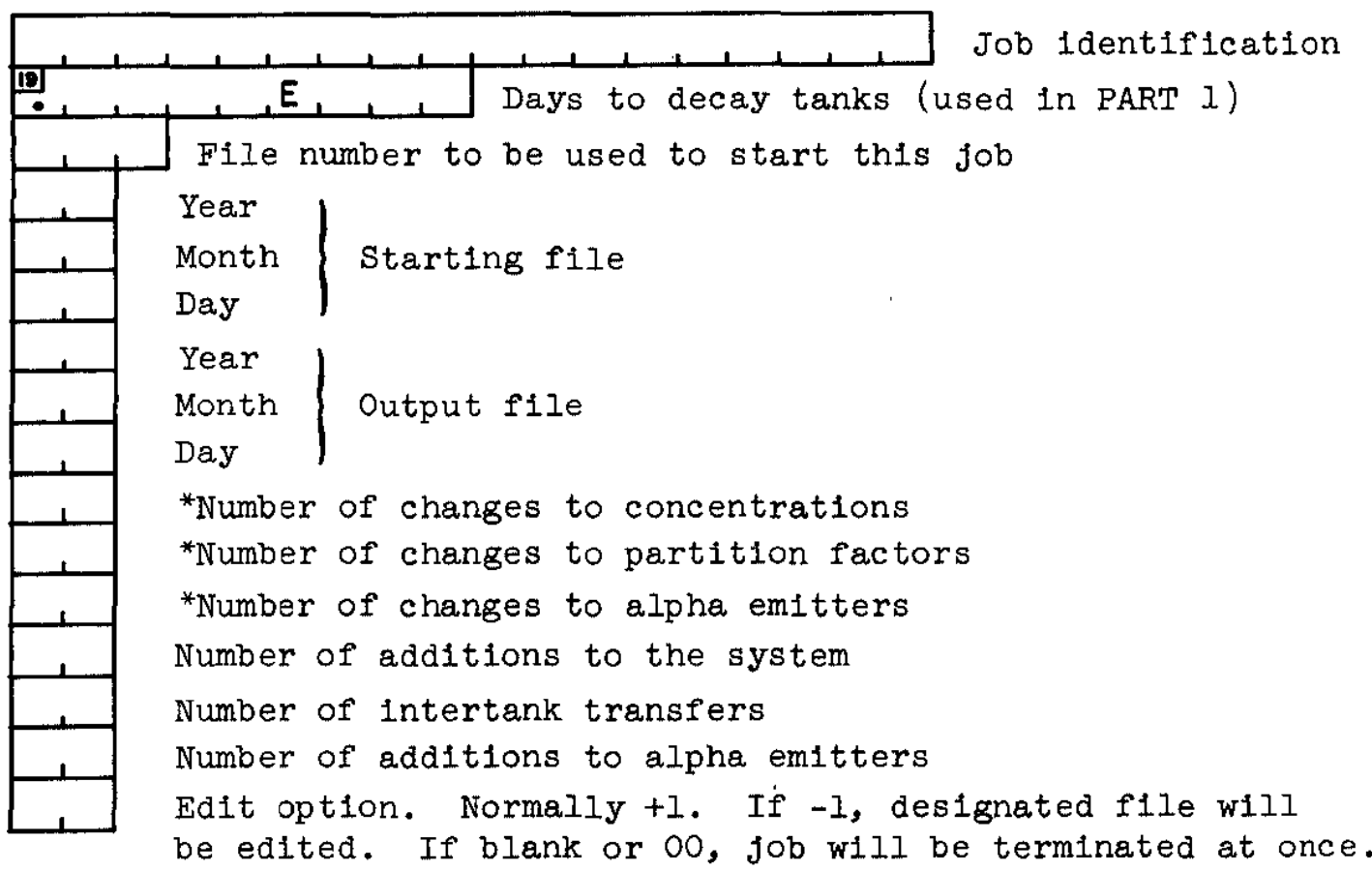

* If any of these are used, the cards to effect the changes must immediately follow this Control Card. 
FIGURE 3

Addition(s) to the System Card - 1 required per addition in a job F $\varnothing$ RMAT (I2, 5E9 . 4, 1A6,I2)

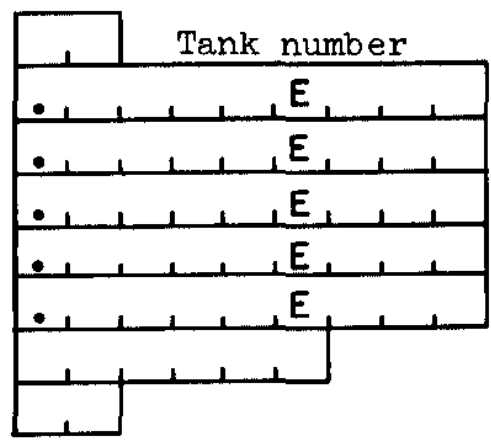

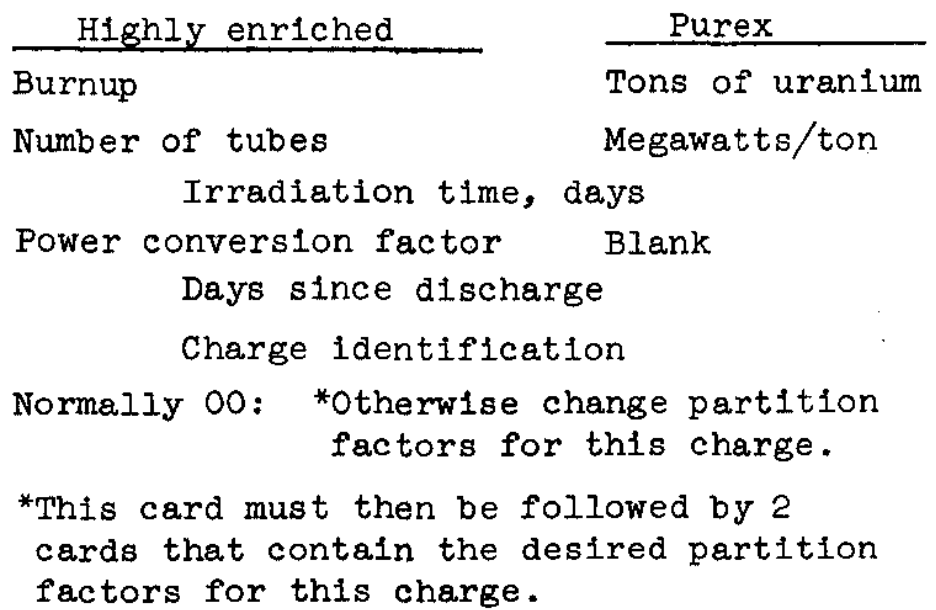

FIGURE 4

Intertank Transfer Card(s) - I required per transfer in a job FøRMAT (2I2, E9 .4,II)

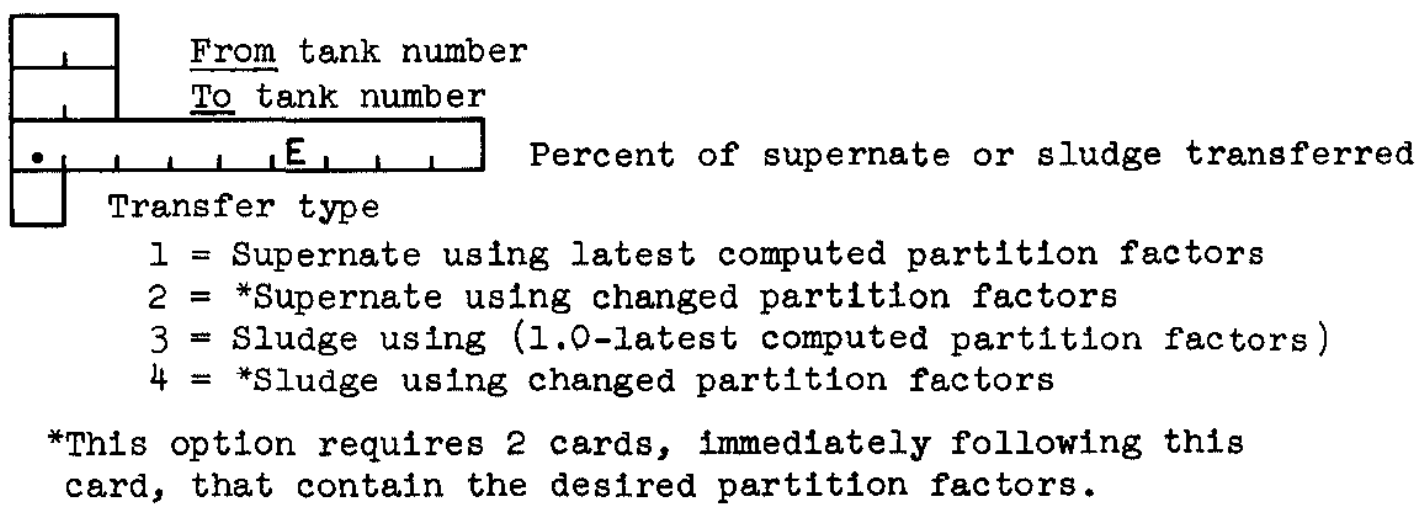




\section{FIGURE 5}

Addition(s) to Alpha Emitter Card - 1 required per addition in a job FØRMAT ( I2, 4E9.4)

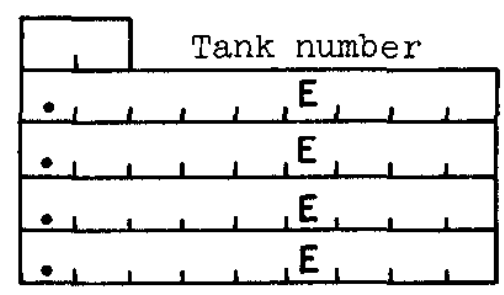

$$
\begin{aligned}
& 2{ }^{38} \mathrm{U}, 10^{3} \mathrm{lb} \\
& 235 \mathrm{U}, \mathrm{kg} \\
& 2{ }^{39} \mathrm{Pu}, \mathrm{kg} \\
& 238-239 \mathrm{Pu} \text {, curies }
\end{aligned}
$$

\section{FIGURE 6}

\section{Change Cards - These 2 cards must immediately follow any option that calls for a change in concentration or partition factors}

F $\varnothing \operatorname{RMAT}(7 \mathrm{X}$, I2 , 6E9 .4/(7E9.4))

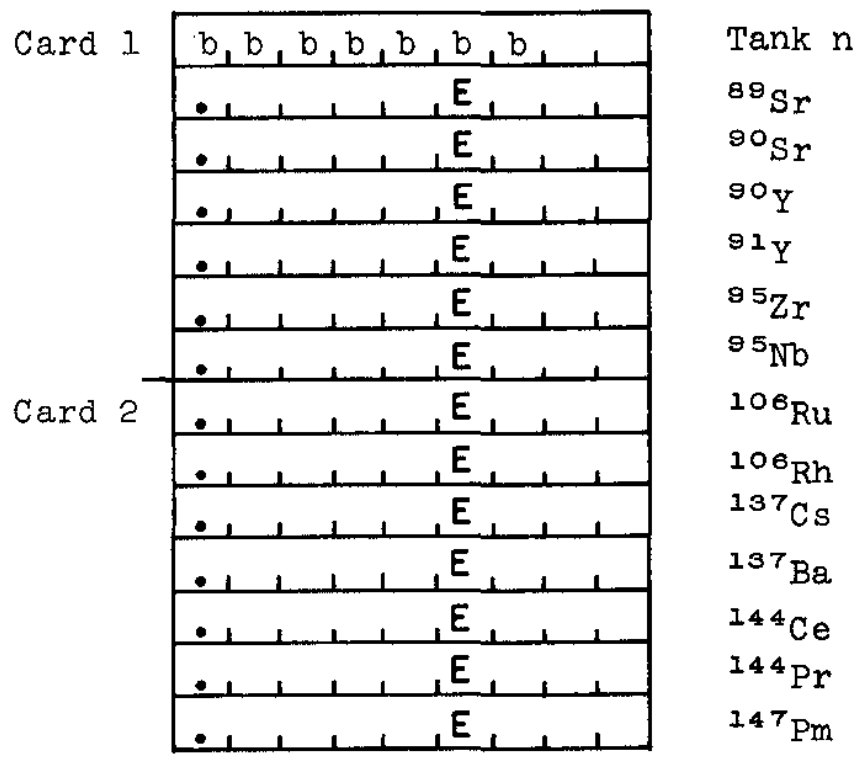




\section{SAMPLE PROBLEM}

The data used in the sample are for a hypothetical problem and bear no relation to the actual tank situation.

The input cards and the printed output for a sample problem are shown in Tables $B-1$ and $B-2$. Change cards for the gamma concentrations in the tanks and tank partition factors were used to put isotopes into the tanks. As indicated on the control card this job consists of four additions from source, four intertank transfers, and two alpha emitter additions.

TABLE B - 1 -Sample Input

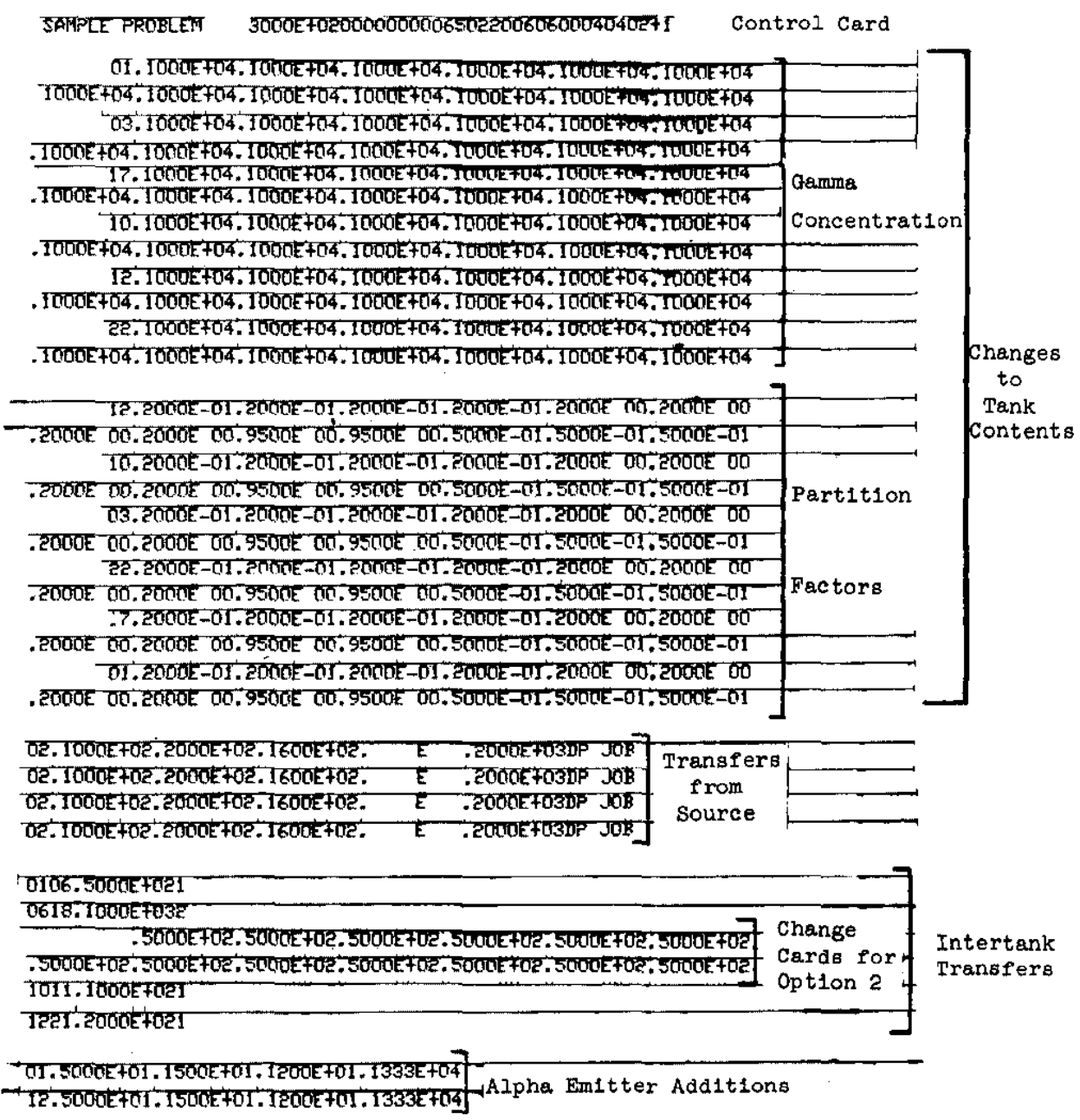


TABLE B-2. Sample Output

CURIES IN TANKS BEFORE AND AFTER DECAY, IF LESS THAN 10 E $\rightarrow 5$ SET $=0.0$.

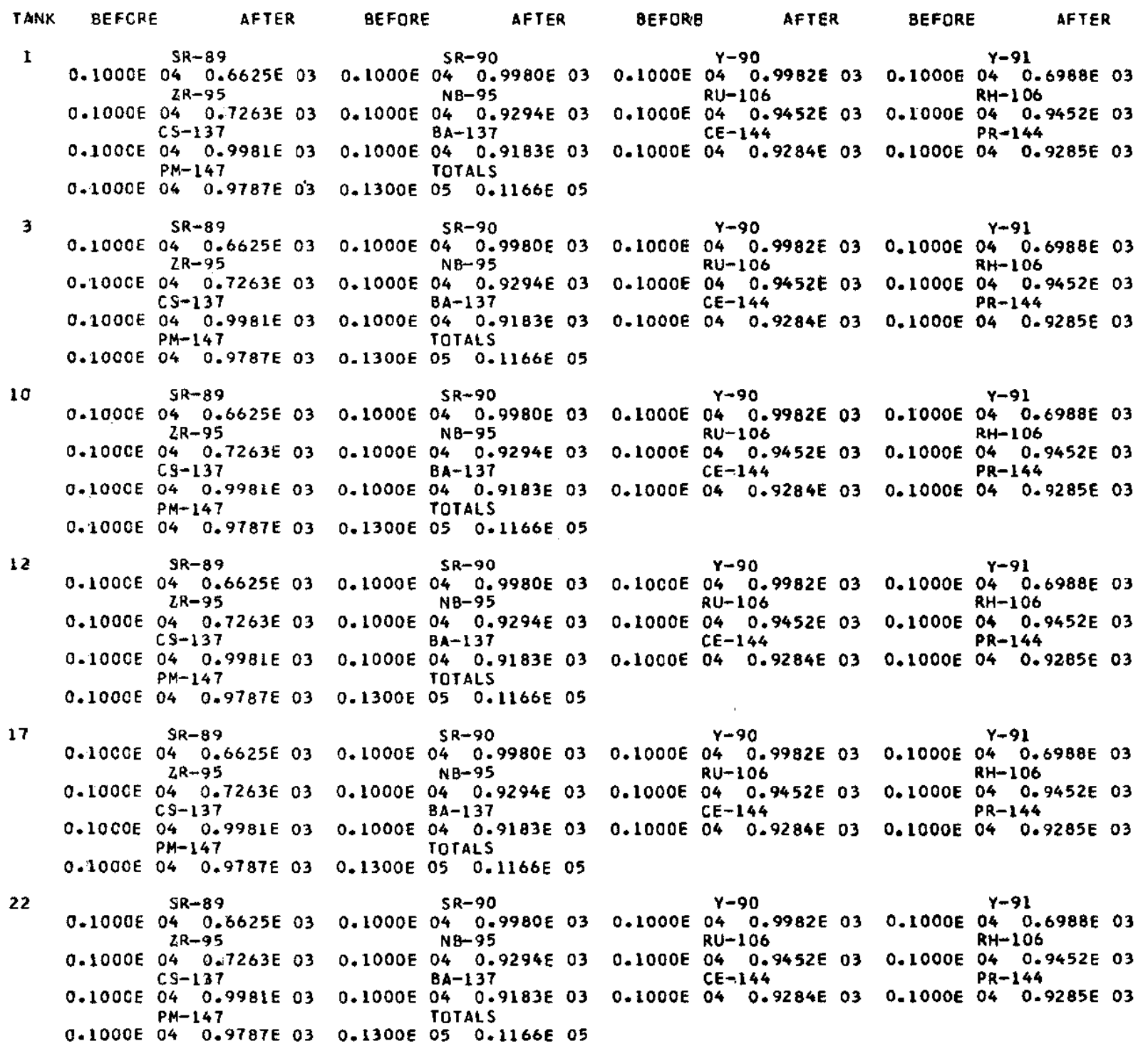


SAMPLE PROBLEM

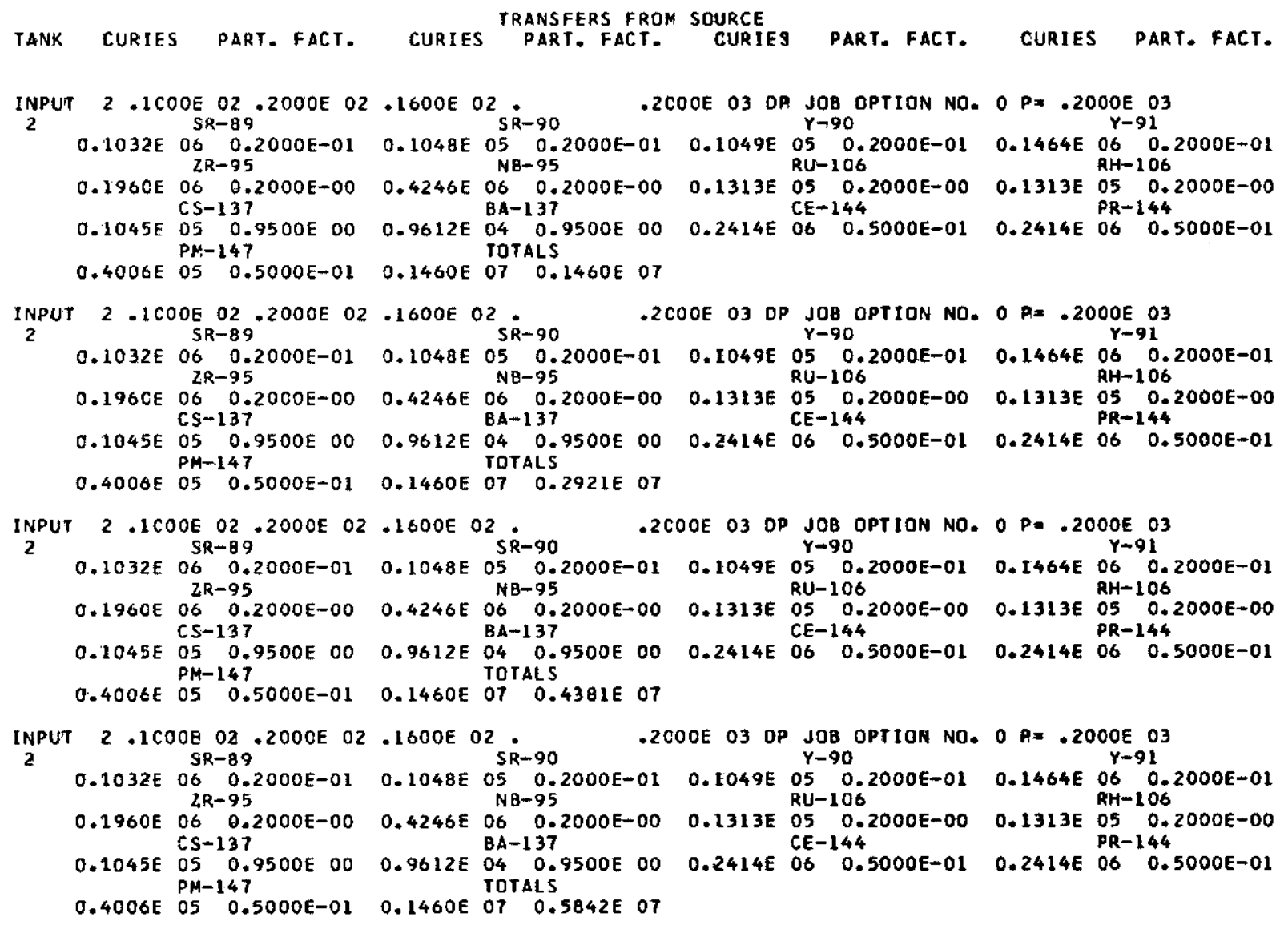


INTERTANK TRANSFERS

INPUT DATA, FROM 2 TO 6 PERCENT MOVED 50.00 OPTION NO. 1

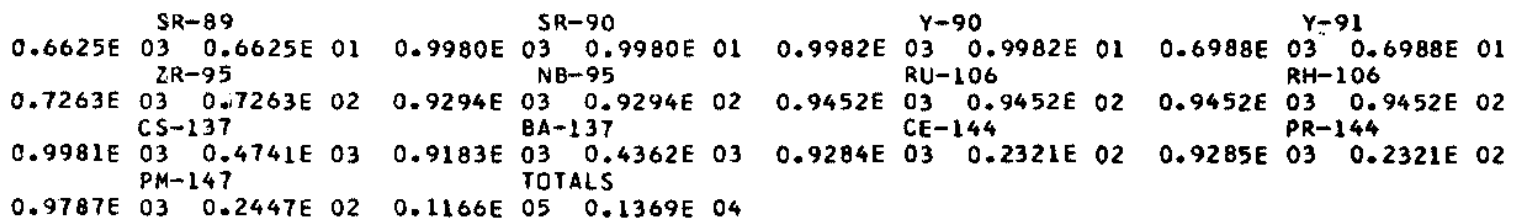

PARTITION FACTOR CHANGES FOR TANK I EACH ISOTOPE BEFORE AND AFTER THE TRANSFER

$0.200 C E-01 \quad 0.1010 E-01 \quad 0.2000 E-01 \quad 0.1010 E-01 \quad 0.2000 E-01 \quad 0.1010 E-01 \quad 0.2000 E-01 \quad 0.1010 E-01$

$0.200 C E-00$ 0.1111E-00 $0.2000 E-00 \quad 0.1111 E-00 \quad 0.2000 E-00 \quad 0.1111 E-00 \quad 0.2000 E-00 \quad 0.1111 E-00$

$0.9500 E$ OO $0.9048 E$ OO $0.9500 E$ OO $0.9048 E$ OO $0.5000 E-01 \quad 0.2564 E-01 \quad 0.5000 E-01 \quad 0.2564 E-01$

$0.500 C E-01 \quad 0.2564 E-01$

PARTITION FAOTOR CHANGES FOR TANK 6 EACH ISOTOPE BEFORE AND AFTER THE TRANSFER

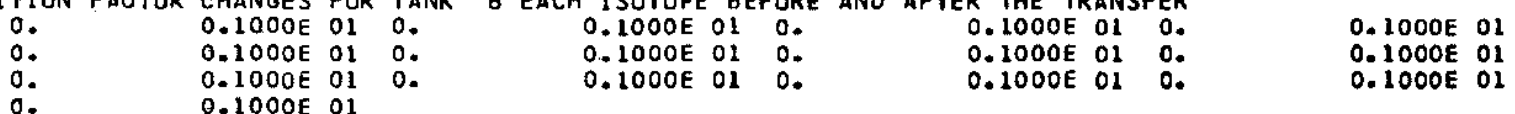

INPUT DATA, FROM 6 TO 18 PERCENT MOVED 100.00 OPTION NO. 2
$0.6625 \mathrm{~F}$ SR-89
$10.6625 E$ OI
$0.7263 E \quad 02 \quad 0.7263 E 02$ C $S-137$
$0.4741 E \quad 030.4741 E 03$ PM- 147
$0.2447 \mathrm{E}$ O2 $0.2447 \mathrm{E} \quad 02$ SR-90
$0.9980 \mathrm{E}$ O1 $0.9980 \mathrm{E}$ 01 $0.9982 \mathrm{E}$
$\mathrm{NB}-95$
$0.9294 \mathrm{E} 02 \quad 0.9294 \mathrm{E} \quad 02 \quad 0.9452 \mathrm{E}$
BA-137
$Y-90$
$010.9982 E$ EI $0.6988 E$ OI $0.6988 E$ OI RU-106

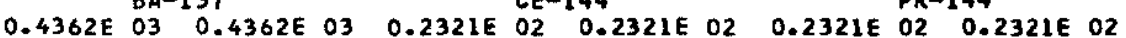 TOTALS
$0.1369 \mathrm{E} 04 \quad 0.1369 \mathrm{E} 04$

PARTITION FACTOR CHANGES FOR TANK 6 EACH ISOTOPE BEFORE AND AFTER THE TRANSFER

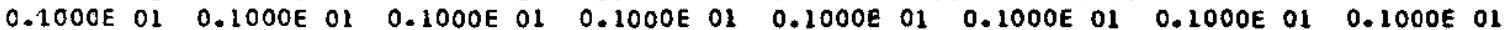

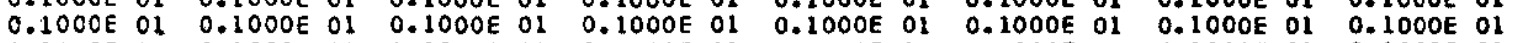

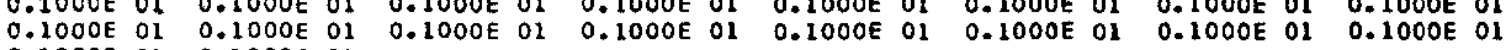

$0.100 C E$ OI $0.1000 E$ OI

PARTITION FACTOR CHANGES FOR TANK 18 EACH ISOTOPE BEFORE AND AFTER THE TRANSFER

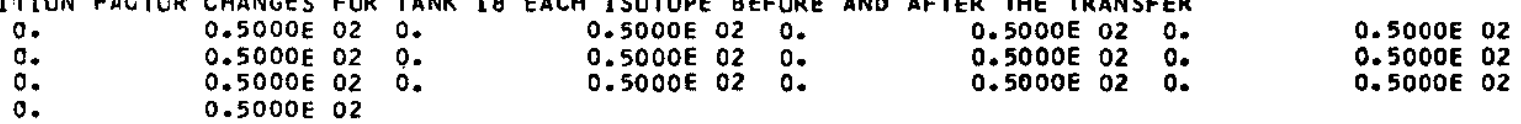


INTERTANK TRANSFERS

INPUT DATA, FROM 10 TC 11 PERCENT MCVED 10.00 OPTION NO. 1

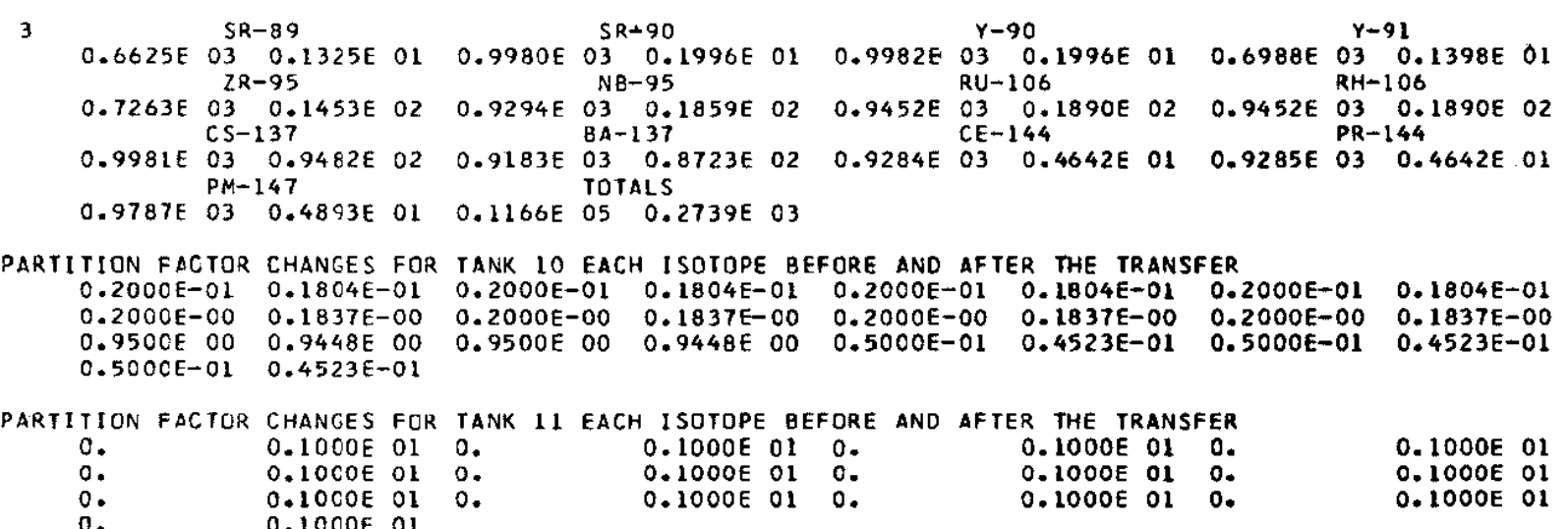

INPUT DATA, FROM 12 TC 21 PERCENT MOVED 20.00 OPTICN NO. 1

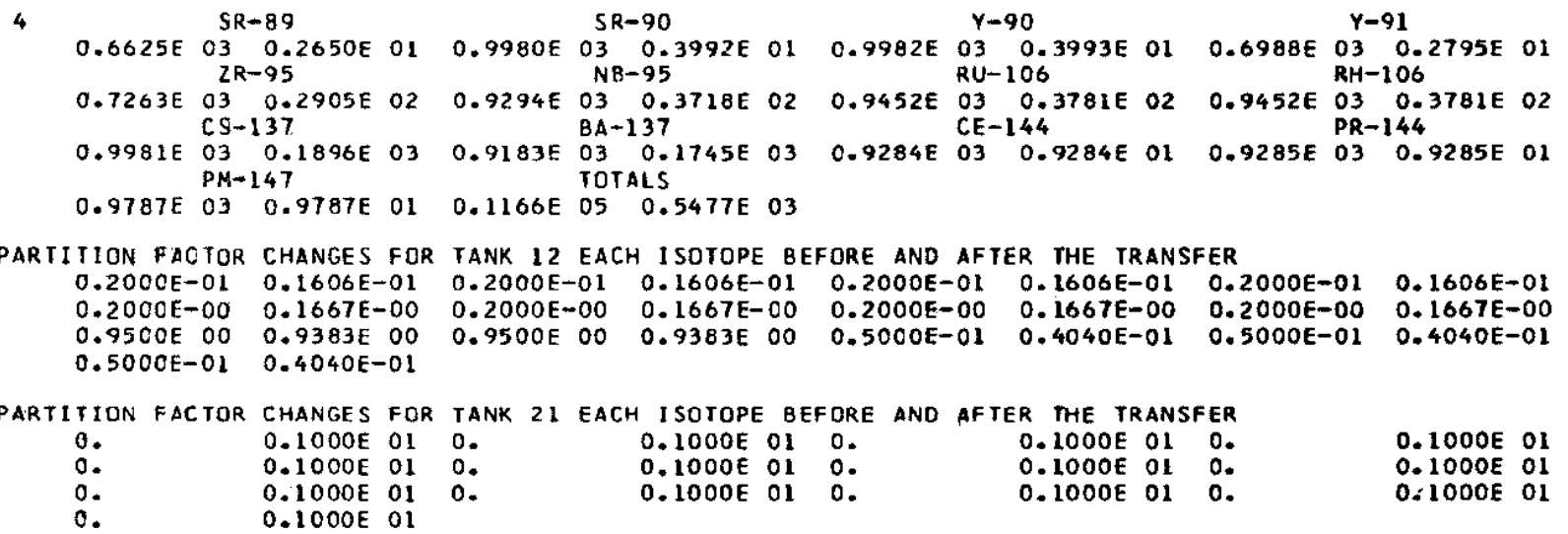


SAMPLE PROBLEM

PARTITION FACIORS AND HEAT (BTU/HR.) FOR EACH ISOTOPE

TANK

ISOTOPES

\begin{tabular}{|c|c|c|c|c|c|c|c|}
\hline 1 & $\begin{array}{l}\text { SR-89 } \\
0.1 \text { C } 10 E-01 \\
\text { RH-106 } \\
\text { O.I } 111 E-00\end{array}$ & $\begin{array}{l}S R-90 \\
0.1010 E-01 \\
C S-137 \\
0.9048 E \quad 00\end{array}$ & $\begin{array}{l}Y-90 \\
0.1010 E-01 \\
B A-137 \\
0.9048 E \quad 00\end{array}$ & $\begin{array}{l}Y-91 \\
0.1010 E-01 \\
C E-144 \\
0.2564 E-01\end{array}$ & $\begin{array}{l}2 R-95 \\
0.1111 E-00 \\
P R-144 \\
0.2564 E-01\end{array}$ & $\begin{array}{l}\text { NB-95 } \\
0.1111 \mathrm{E}-00 \\
\text { PH-147 } \\
0.2564 \mathrm{E}-01\end{array}$ & $\begin{array}{l}R \cup-106 \\
0.1111 E-00\end{array}$ \\
\hline 1 & $\begin{array}{c}S R-89 \\
0.64288 \text { OI } \\
\text { RH }=106 \\
0.2875 E \quad 02\end{array}$ & $\begin{array}{l}S R-90 \\
0.3359 E \text { O1 } \\
C S-137 \\
0.1782 E \text { O1 }\end{array}$ & $\begin{array}{ccc}Y-90 \\
0.1799 E & 02 \\
B A-137 & \\
0.7038 E & 01\end{array}$ & $\begin{array}{c}Y-91 \\
0.7056 \mathrm{E} \quad 01 \\
\text { CE-144 } \\
0.1992 \mathrm{E} \quad 01\end{array}$ & $\begin{array}{ll}\begin{array}{l}2 R-95 \\
0.1111 E\end{array} & 02 \\
P R-144 & \\
0.2281 E & 02\end{array}$ & $\begin{array}{cc}N B-95 & \\
0.1338 E & 02 \\
P M-147 & \\
0.1183 E & 01\end{array}$ & $\begin{array}{c}R U-106 \\
0.1701 E=00\end{array}$ \\
\hline 2 & $\begin{array}{c}\text { SR-89 } \\
0.2 \text { COOE-01 } \\
R H-106 \\
C .2000 E-00\end{array}$ & $\begin{array}{c}S R-90 \\
0.2000 E-01 \\
C S-137 \\
0.9500 E \text { OO }\end{array}$ & $\begin{array}{l}Y-90 \\
0.2000 E-01 \\
B A-137 \\
0.9500 E \quad 0 O\end{array}$ & $\begin{array}{l}Y-91 \\
0.2000 E-01 \\
C E-144 \\
0.5000 E-01\end{array}$ & $\begin{array}{c}2 R-95 \\
0.2000 E-00 \\
P R-144 \\
0.5000 E=01\end{array}$ & $\begin{array}{l}N B-95 \\
0.2000 E-00 \\
P M-147 \\
0.5000 E-01\end{array}$ & $\begin{array}{l}R U-106 \\
0.2000 E-00\end{array}$ \\
\hline 2 & $\begin{array}{c}S R-89 \\
0.4 C 45 E \quad 04 \\
R H-106 \\
0.1776 E \quad 04\end{array}$ & $\begin{array}{l}\text { SR-90 } \\
0.1426 E \text { O3 } \\
\text { CS-137 } \\
0.1421 E \quad 03\end{array}$ & $\begin{array}{cc}Y-90 \\
0.7633 \mathrm{E} & 03 \\
B A-137 & \\
0.5614 \mathrm{E} & 03\end{array}$ & $\begin{array}{c}Y-91 \\
0.5974 E \quad 04 \\
C E-144 \\
0.2124 E\end{array}$ & $\begin{array}{l}2 R-95 \\
0.1333 E \text { O5 } \\
P R=144 \\
0.2433 E\end{array}$ & $\begin{array}{ll}N B-95 & \\
0.2718 E & 05 \\
P M-147 & \\
0.1987 E & 03\end{array}$ & $\begin{array}{ll}R U-106 & \\
0.1051 E & 02\end{array}$ \\
\hline 3 & $\begin{array}{c}\text { SR-89 } \\
0.2 \text { COOE-01 } \\
R H \rightarrow 106 \\
0.2000 \mathrm{E}-00\end{array}$ & $\begin{array}{c}S R-90 \\
0.2000 E-01 \\
\text { CS-137 } \\
0.9500 E \quad 00\end{array}$ & $\begin{array}{l}Y-90 \\
0.2000 E-01 \\
B A-137 \\
0.9500 E \quad 00\end{array}$ & $\begin{array}{l}Y-91 \\
0.20 C 0 E-01 \\
C E-144 \\
0.5000 E-01\end{array}$ & $\begin{array}{l}2 R-95 \\
0.2000 E-00 \\
P R-144 \\
0.5000 E-01\end{array}$ & $\begin{array}{l}N B-95 \\
0.2000 E-00 \\
P M-147 \\
0.5000 E-01\end{array}$ & $\begin{array}{c}R U-106 \\
0.2000 E-00\end{array}$ \\
\hline 3 & $\begin{array}{c}\text { SR-89 } \\
0.64936 \text { o1 } \\
\text { RH-106 } \\
0.3195 E \quad 02\end{array}$ & $\begin{array}{c}S R-90 \\
0.3393 E \text { OL } \\
C S-137 \\
0.3394 E \text { Ol }\end{array}$ & $\begin{array}{ccc}Y-90 \\
0.1817 E & 02 \\
B A-137 & \\
0.1341 E & 02\end{array}$ & $\begin{array}{l}Y-91 \\
0.7127 E \text { ol } \\
C E-144 \\
0.2043 E \quad 01\end{array}$ & $\begin{array}{cc}2 R-95 & \\
0.1235 E & 02 \\
P R-144 & \\
0.2340 E & 02\end{array}$ & $\begin{array}{ll}\text { NB-95 } & \\
0.1487 E & 02 \\
P M-147 & \\
0.1214 E & 01\end{array}$ & $\begin{array}{c}R U-106 \\
0.1890 E-00\end{array}$ \\
\hline 6 & $\begin{array}{c}\text { SR-89 } \\
0.1 \text { COOE O1 } \\
\text { RH-106 } \\
0.1000 E \text { O1 }\end{array}$ & $\begin{array}{l}\text { SR-90 } \\
0.1000 E \text { OL } \\
C S-137 \\
0.1000 E \text { O1 }\end{array}$ & $\begin{array}{cc}Y-90 \\
0.1000 \mathrm{E} & 01 \\
B A-137 & \\
0.1000 E & 01\end{array}$ & $\begin{array}{l}Y-91 \\
0.1000 E \text { O1 } \\
\text { CE-144 } \\
0.1000 E \quad 01\end{array}$ & $\begin{array}{c}2 R-95 \\
0.1000 E \text { OL } \\
P R-144 \\
0.1000 E \text { Ol }\end{array}$ & $\begin{array}{c}\text { NB-95 } \\
0.1000 E \text { O1 } \\
\text { PM-147 } \\
0.1000 E \text { O1 }\end{array}$ & $\begin{array}{l}\mathrm{AU}-106 \\
0.1000 \mathrm{E} 01\end{array}$ \\
\hline 6 & $\begin{array}{c}5 R-89 \\
0.1168 E-08 \\
R H-106 \\
0.6447 E-07\end{array}$ & $\begin{array}{c}\text { SR-90 } \\
0.8106 \mathrm{E}-09 \\
\text { CS-137 } \\
0.2594 \mathrm{E}-07\end{array}$ & $\begin{array}{c}Y-90 \\
0.4339 E-08 \\
B A-137 \\
0.1114 E-06\end{array}$ & $\begin{array}{l}\gamma-91 \\
0.1216 E-08 \\
C E-144 \\
0.1049 E-08\end{array}$ & $\begin{array}{l}2 R-95 \\
0.3242 E-07 \\
P R-144 \\
0.1202 E-07\end{array}$ & $\begin{array}{l}N B-95 \\
0.3052 E-07 \\
P M-147 \\
0.5913 E-09\end{array}$ & $\begin{array}{c}R U-106 \\
0.3815 E-09\end{array}$ \\
\hline & $\begin{array}{c}\text { SR-89 } \\
0.18046-01 \\
\text { RH- } 106 \\
C .1837 E-00\end{array}$ & $\begin{array}{l}S R-90 \\
0.1804 E-01 \\
C S-137 \\
0.9448 E \text { OO }\end{array}$ & $\begin{array}{l}Y-90 \\
0.1804 E-01 \\
B A-137 \\
0.9448 E \quad 00\end{array}$ & $\begin{array}{l}Y-91 \\
0.1804 E-01 \\
C E-144 \\
0.4523 E-01\end{array}$ & $\begin{array}{c}2 R-95 \\
0.1837 E-00 \\
P R-144 \\
0.4523 E-01\end{array}$ & $\begin{array}{l}N B-95 \\
0.1837 E-00 \\
\text { PM-147 } \\
0.4523 E-01\end{array}$ & $\begin{array}{c}\mathrm{RU}-106 \\
0.1837 \mathrm{E}-00\end{array}$ \\
\hline & $\begin{array}{c}S R-89 \\
0.6480 E \text { O1 } \\
R H-106 \\
C .3131 E \quad 02\end{array}$ & $\begin{array}{c}\text { SR-90 } \\
0.3386 E \text { O1 } \\
\text { CS-137 } \\
0.3071 E \text { O1 }\end{array}$ & $\begin{array}{ccc}\begin{array}{c}\gamma-9 \\
0.1813 E\end{array} & 02 \\
8 A-137 & & \\
0.1213 E & 02\end{array}$ & 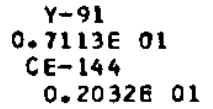 & $\begin{array}{ccc}2 R-95 & \\
0.1210 E & 02 \\
P R-144 & \\
0.2328 E & 02\end{array}$ & $\begin{array}{c}N 8-95 \\
0.1457 E \text { O2 } \\
\text { PM-147 } \\
0.1207 E \text { O1 }\end{array}$ & $\begin{array}{c}R U-106 \\
0.1853 E-00\end{array}$ \\
\hline
\end{tabular}


SAMPLE PROBLEM

PARTITION FACTORS AND HEAT (BTU/HR.) FOR EACH ISOTOPE

TANK

ISCTOPES

\begin{tabular}{|c|c|c|c|c|c|c|c|}
\hline 11 & $\begin{array}{l}\text { \$R-89 } \\
0.1 C O O E \text { O1 } \\
\text { RF-106 } \\
\text { C.1OOOE O1 }\end{array}$ & $\begin{array}{c}S R-90 \\
C .1000 E \text { O1 } \\
C S-137 \\
0.1000 E \text { O1 }\end{array}$ & $\begin{array}{l}Y-90 \\
0.1000 E \text { OL } \\
B A-137 \\
0.1000 E \text { O1 }\end{array}$ & $\begin{array}{l}Y-91 \\
0.1000 \text { O O1 } \\
C E-144 \\
0.1000 E \quad C 1\end{array}$ & $\begin{array}{l}2 R-95 \\
0.1000 E \text { O1 } \\
P R-144 \\
0.1000 E \text { O1 }\end{array}$ & $\begin{array}{ll}N B-95 & \\
0.1000 E & 01 \\
P M-147 & \\
0.1000 E & 01\end{array}$ & $\begin{array}{l}R U-106 \\
0.1000 E \quad 01\end{array}$ \\
\hline & $\begin{array}{c}\text { SR-89 } \\
0.1299 \mathrm{E}-01 \\
\text { RH-106 } \\
0.6390 \mathrm{E} \quad 00\end{array}$ & $\begin{array}{c}S R-90 \\
0.6786 E-02 \\
C S-137 \\
0.3224 E-00\end{array}$ & $\begin{array}{l}Y-90 \\
0.3634 E-01 \\
B A-137 \\
0.1274 E \quad 01\end{array}$ & $\begin{array}{l}Y-91 \\
0.1425 E-01 \\
C E-144 \\
0.1021 E-01\end{array}$ & $\begin{array}{l}Z R-95 \\
0.2469 E-00 \\
P R-144 \\
0.1170 E-00\end{array}$ & $\begin{array}{c}N B-95 \\
0.2974 E-00 \\
P M-147 \\
0.6068 E-02\end{array}$ & $\begin{array}{c}R U-106 \\
0.3781 E-02\end{array}$ \\
\hline & $\begin{array}{c}S R-89 \\
0.1606 E-01 \\
R H-106 \\
0.1667 \mathrm{E}-00\end{array}$ & $\begin{array}{l}S R-90 \\
0.1606 E-01 \\
C S-137 \\
0.9383 E \quad 00\end{array}$ & $\begin{array}{l}Y-90 \\
0.1606 E-01 \\
B A-137 \\
0.9383 E .00\end{array}$ & $\begin{array}{c}Y-91 \\
0.16 C 6 E-01 \\
C E-144 \\
0.4040 E-01\end{array}$ & $\begin{array}{c}2 R-95 \\
0.1667 E-00 \\
P R-144 \\
0.4040 E-01\end{array}$ & $\begin{array}{l}N B-95 \\
0.1667 E-00 \\
P M-147 \\
0.4040 E-01\end{array}$ & $\begin{array}{l}R U-106 \\
0.1667 E-00\end{array}$ \\
\hline & $\begin{array}{c}\text { SR-89 } \\
0.6467 E \text { O1 } \\
\text { RH-106 } \\
C .3067 E \quad 02\end{array}$ & $\begin{array}{l}S R-90 \\
0.3380 E \text { Ol } \\
C S-137 \\
C .2749 E \text { Ol }\end{array}$ & $\begin{array}{ccc}Y-90 & \\
0.1810 E & 02 \\
B A-137 & & \\
0.1086 E & 02\end{array}$ & $\begin{array}{l}Y-91 \\
0.7099 E \text { OL } \\
\text { CE- } 144 \\
0.2022 E \quad 01\end{array}$ & $\begin{array}{ccc}2 R-95 \\
0.1185 E & 02 \\
P R-144 & \\
0.2316 E & 02\end{array}$ & $\begin{array}{cc}N B-95 & \\
0.1428 E & 02 \\
P M-147 & \\
0.1201 E & 01\end{array}$ & $\begin{array}{c}R U-106 \\
0.1815 E-00\end{array}$ \\
\hline & $\begin{array}{c}\text { SR-89 } \\
0.2 C O O E-01 \\
R F-106 \\
C .2000 E-00\end{array}$ & $\begin{array}{l}S R-90 \\
0.2000 E-01 \\
C S-137 \\
0.9500 E \quad 00\end{array}$ & $\begin{array}{l}Y-90 \\
0.2000 E-01 \\
8 A-137 \\
0.9500 E \quad 00\end{array}$ & $\begin{array}{l}Y-91 \\
0.2000 E-01 \\
C E-144 \\
0.5000 E-01\end{array}$ & $\begin{array}{l}2 R-95 \\
0.2000 E-00 \\
P R-144 \\
0.5000 E-01\end{array}$ & $\begin{array}{l}N B-95 \\
0.2000 E-00 \\
P M-147 \\
0.5000 E-01\end{array}$ & $\begin{array}{l}R U-106 \\
0.2000 E-00\end{array}$ \\
\hline & $\begin{array}{c}\text { SR-89 } \\
0.6493 E \quad 01 \\
R R-106 \\
0.3195 E \quad 02\end{array}$ & $\begin{array}{c}S R-90 \\
0.3393 E \text { Ol } \\
C S-137 \\
0.3394 \mathrm{E} \text { O1 }\end{array}$ & $\begin{array}{ccc}Y-90 \\
0.1817 E & 02 \\
B A-137 & \\
0.1341 E & 02\end{array}$ & $\begin{array}{l}Y-91 \\
0.7127 \mathrm{E} \quad 01 \\
C E-144 \\
0.2043 \mathrm{E} \quad 01\end{array}$ & $\begin{array}{ll}2 R-95 & \\
0.1235 E & 02 \\
P R-144 & \\
0.2340 E & 02\end{array}$ & $\begin{array}{ccc}N B-95 & \\
0.1487 E & 02 \\
P M-147 & & \\
0.1214 E & 01\end{array}$ & $\begin{array}{l}R U-106 \\
0.18905-00\end{array}$ \\
\hline & $\begin{array}{c}\text { SR-89 } \\
0.5 C O O E \text { O2 } \\
\text { RH-106 } \\
0.5000 E \text { O2 }\end{array}$ & $\begin{array}{l}S R-90 \\
0.5000 E \text { O2 } \\
C S-137 \\
0.5000 E \quad 02\end{array}$ & $\begin{array}{cc}Y-90 & \\
0.5000 E & O 2 \\
8 A-137 & \\
0.5000 E & 02\end{array}$ & $\begin{array}{c}Y-91 \\
0.50 C O E \text { OZ } \\
C E-144 \\
0.5000 E \quad 02\end{array}$ & $\begin{array}{cc}2 R-95 & \\
0.5000 E & 02 \\
P R-144 & \\
0.5000 E & 02\end{array}$ & $\begin{array}{l}\text { NB-95 } \\
0.5000 E \text { O2 } \\
\text { PM- } 147 \\
0.5000 E \quad 02\end{array}$ & $\begin{array}{ll}R U-106 & \\
0.5000 E \quad 02\end{array}$ \\
\hline & $\begin{array}{c}S R-89 \\
0.6493 E-01 \\
R r-106 \\
C .3195 E \quad 01\end{array}$ & $\begin{array}{c}S R-90 \\
0.3393 E-01 \\
C S-137 \\
C .1612 E \quad 01\end{array}$ & $\begin{array}{l}Y-90 \\
0.1817 \mathrm{E}-00 \\
B A-137 \\
0.6368 \mathrm{E} \quad 01\end{array}$ & $\begin{array}{l}Y-91 \\
0.7127 \mathrm{E}-01 \\
\mathrm{CE}-144 \\
0.5106 \mathrm{E}-01\end{array}$ & $\begin{array}{ll} & 2 R-95 \\
0.1235 E & 01 \\
P R-144 & \\
0.5849 E & 00\end{array}$ & $\begin{array}{l}N B-95 \\
0.1487 E \text { O1 } \\
P M-147 \\
0.3034 E-01\end{array}$ & $\begin{array}{l}\text { RU-106 } \\
0.1890 E-01\end{array}$ \\
\hline & $\begin{array}{l}\text { SR-89 } \\
0.1 C O O E \text { OI } \\
\text { RH-106 } \\
C .1000 E \text { Ol }\end{array}$ & $\begin{array}{l}\text { SR-90 } \\
0.1000 E \text { O1 } \\
C S-137 \\
C .1000 E \text { O1 }\end{array}$ & $\begin{array}{l}Y-90 \\
0.1000 \mathrm{E} \text { OL } \\
B A-137 \\
0.1000 \mathrm{E} \quad 01\end{array}$ & $\begin{array}{ccc}Y-91 \\
0.10 C O E & 01 \\
C E-144 & \\
0.1000 E & 01\end{array}$ & $\begin{array}{cc}2 R-95 & \\
0.1000 E & 01 \\
P R-144 & \\
0.1000 E & 01\end{array}$ & $\begin{array}{l}N B-95 \\
0.1000 E \text { Ol } \\
\text { PM-147 } \\
0.1000 E \text { O1 }\end{array}$ & $\begin{array}{l}R U-106 \\
0.1000 E \text { O1 }\end{array}$ \\
\hline & $\begin{array}{cc}S R-89 \\
0.2597 E-01 \\
\text { RH }-106 \\
C .1278 E \quad 01\end{array}$ & $\begin{array}{l}S R-90 \\
0.1357 E-01 \\
C S-137 \\
0.6448 E \quad 00\end{array}$ & $\begin{array}{l}Y-90 \\
0.7267 E-01 \\
B A-137 \\
0.2547 E \quad 01\end{array}$ & $\begin{array}{l}Y-91 \\
0.2851 \mathrm{E}-01 \\
C E-144 \\
0.2043 \mathrm{E}-\mathrm{Cl}\end{array}$ & $\begin{array}{l}5 \\
E-00 \\
40 E-00\end{array}$ & $\begin{array}{l}N B-95 \\
0.5948 E \quad 00 \\
P M-147 \\
0.1214 E-01\end{array}$ & $\begin{array}{c}R U-106 \\
0.7562 E-02\end{array}$ \\
\hline & $\begin{array}{c}S R-89 \\
0.2 C 00 E-01 \\
R H-106 \\
0.2000 E-00\end{array}$ & $\begin{array}{c}S R-90 \\
0.2000 E-01 \\
C S-137 \\
0.9500 E \quad 00\end{array}$ & $\begin{array}{l}Y-90 \\
0.2000 E-01 \\
B A-137 \\
0.9500 E 00\end{array}$ & $\begin{aligned} & Y-91 \\
& 0 . 20 C O E-01 \\
& C E-144 \\
& \\
& C .5000 E-01\end{aligned}$ & $\begin{array}{l}2 R-95 \\
0.2000 E-00 \\
P R-144 \\
0.5000 E-01\end{array}$ & $\begin{array}{l}N B-95 \\
0.2000 E-00 \\
P M-147 \\
0.5000 E-01\end{array}$ & $\begin{array}{c}R U-106 \\
0.2000 E-00\end{array}$ \\
\hline 22 & $\begin{array}{c}\text { SR-89 } \\
0.6493 E \text { O1 } \\
\text { Rr-106 } \\
0.3195 E \quad 02\end{array}$ & $\begin{array}{c}S R-90 \\
0.3393 E \quad 01 \\
C S-137 \\
0.3394 E \quad 01\end{array}$ & 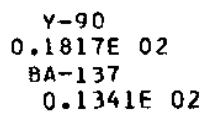 & $\begin{array}{ccc}Y-91 \\
0.7127 E & 01 \\
C E-144 & \\
0.2043 E & 01\end{array}$ & 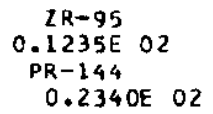 & $\begin{array}{ll}\begin{array}{l}N B-95 \\
0.1487 E\end{array} & 02 \\
P M-147 & \\
0.1214 E & 01\end{array}$ & $\begin{array}{l}R U-106 \\
0.1890 E-00\end{array}$ \\
\hline
\end{tabular}




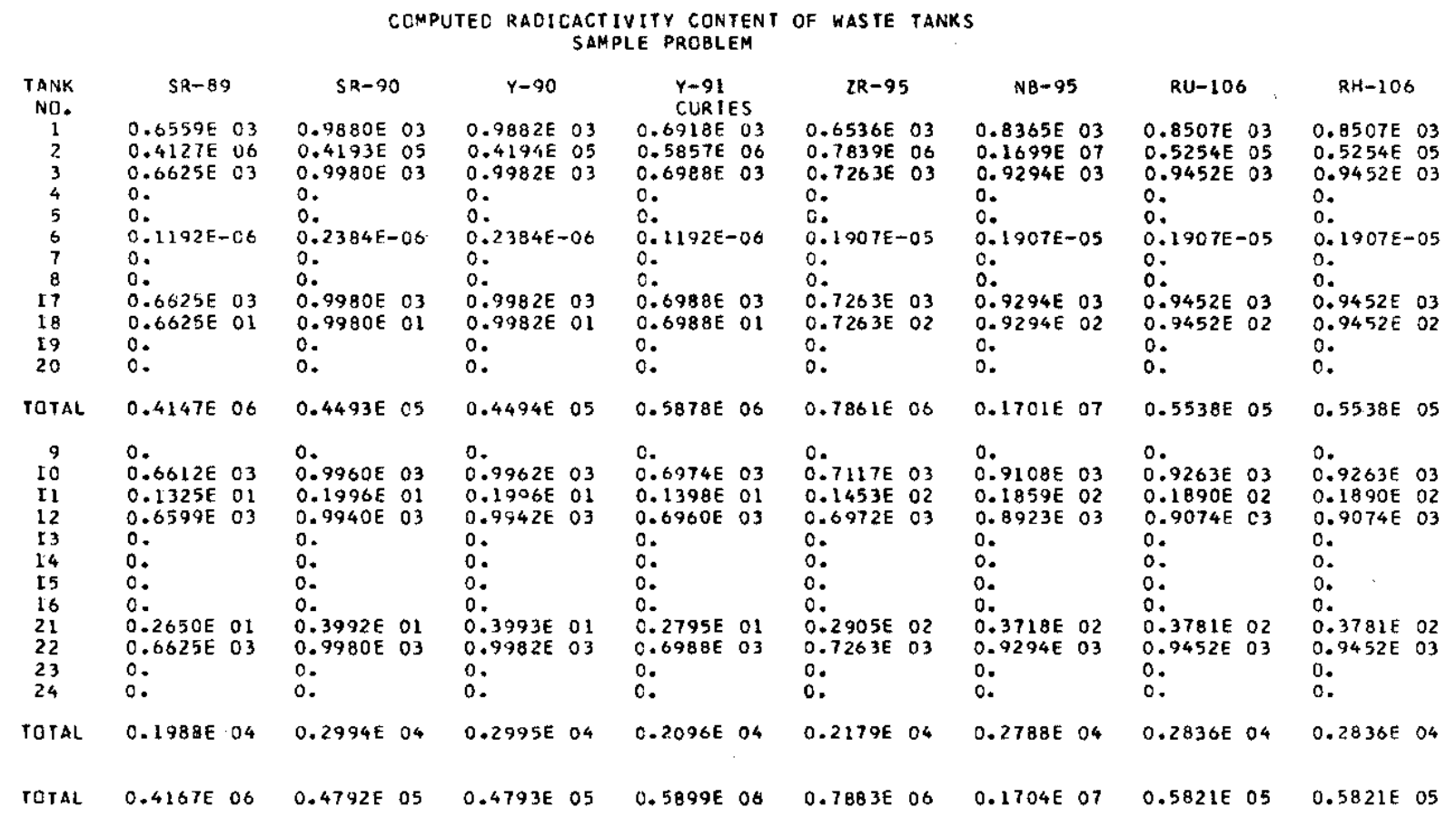

CCMPUTEE RAC CACTIVITY CONTENT OF WASTE TANKS SAMPLE PROBLEM

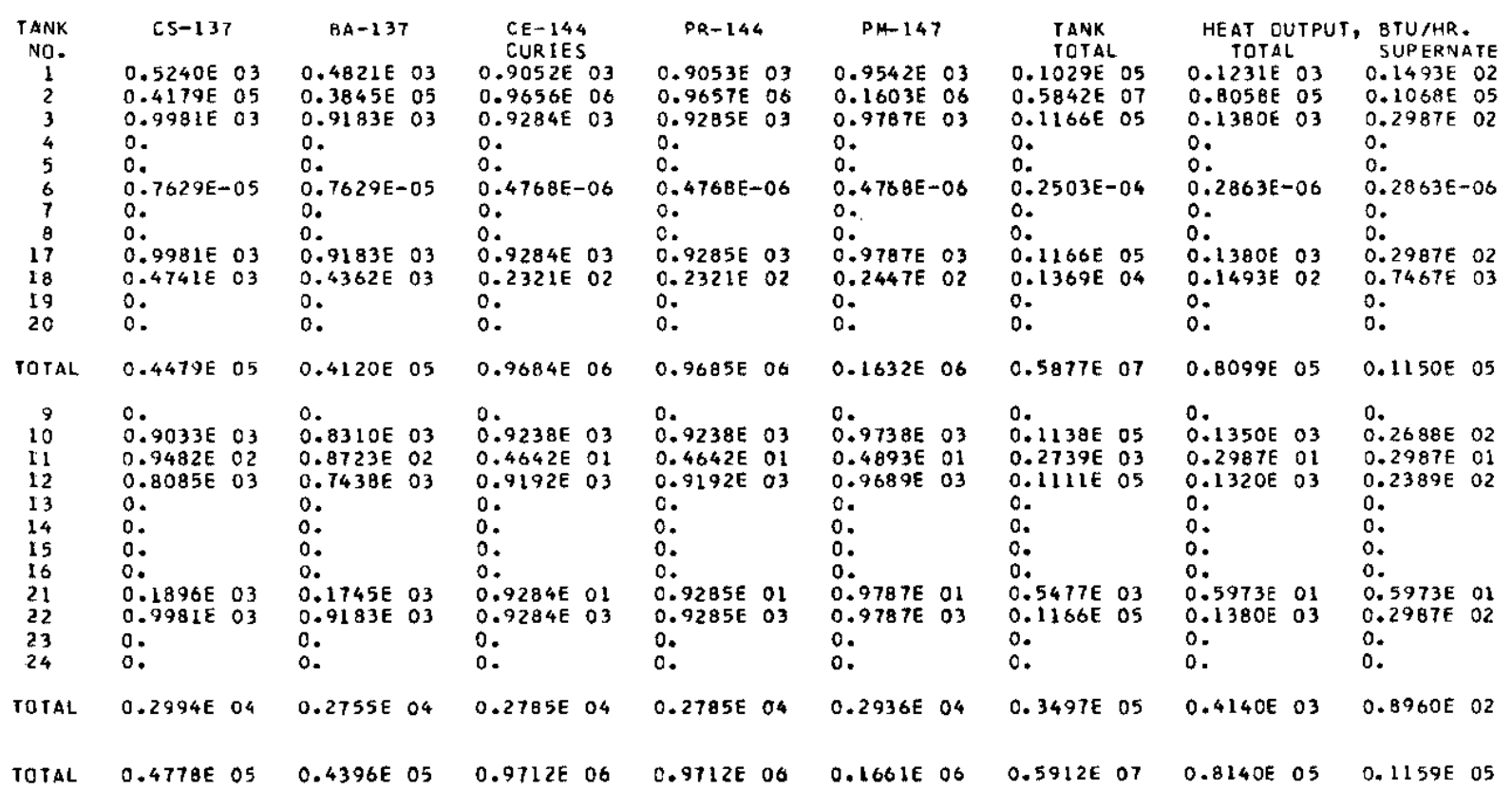


COMPUTED RADIOACTIVITY CONTENT OF WASTE TANKS SAMPLE PROBLEN

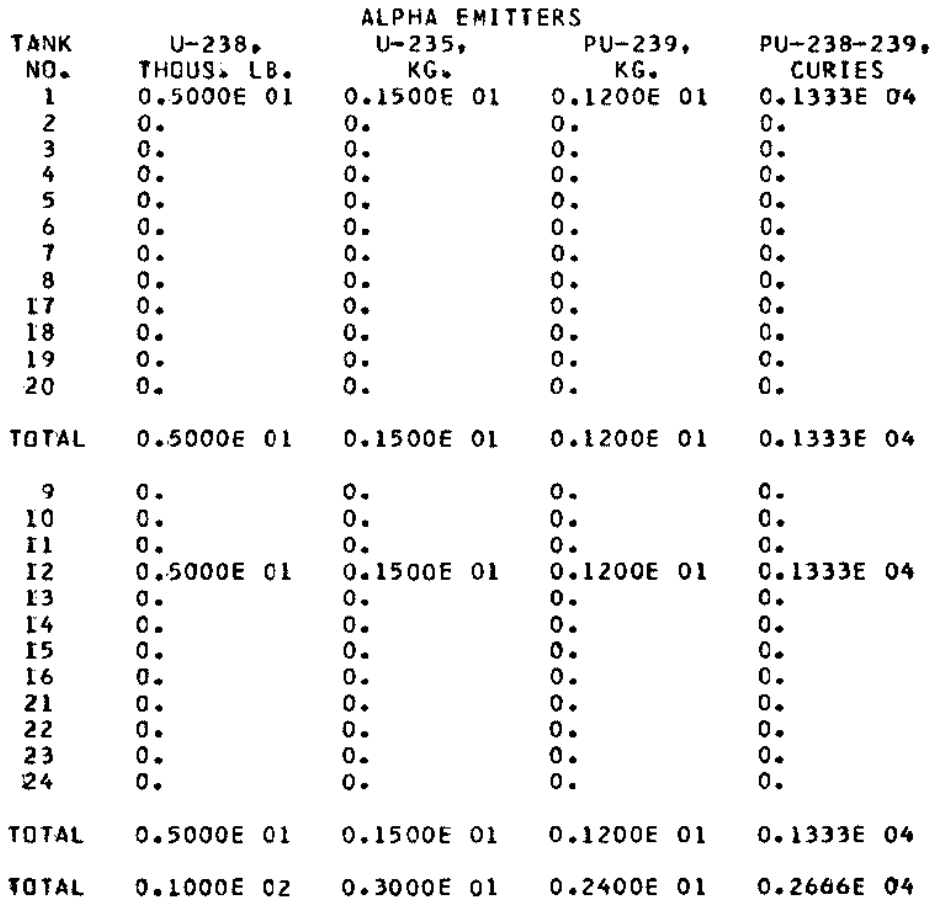

SAMPLE PROBLEM

SUMMARY SHEET FOR THIS JCB.

TANKS DECAYED FCR 30. DAYS

FILE NUMBER O WITH THIS DATE 0.10 .10 . WAS USED AS THE STARTING POINT

FILE NUMBER I WITH THIS DATE 65./ 2.120. SHDULD BE USED AS THE STARTING POINT FOR THE NEXT JOB. THE CURIES IN THE LIBRARY FILE WERE CHANGED 6 TIMES

THE PARTITION FACTORS WERE CHANGED 6 TIMES

THE ALPHA EMITTERS WERE CHANGED O IIMES

THERE WERE 4 CHARGES ADDED TO THE SYSTEM

THERE WERE 4 INTERTANK TRANSFERS

THERE WERE 2 ADDITIONS TO THE ALPHA EMITTERS 